\title{
The geography of European cross-border banking: the impact of cultural and political factors
}

Citation for published version (APA):

Heuchemer, S., Kleimeier, S., \& Sander, H. (2008). The geography of European cross-border banking: the impact of cultural and political factors. METEOR, Maastricht University School of Business and Economics. METEOR Research Memorandum No. 008 https://doi.org/10.26481/umamet.2008008

Document status and date:

Published: 01/01/2008

DOI:

10.26481/umamet.2008008

Document Version:

Publisher's PDF, also known as Version of record

\section{Please check the document version of this publication:}

- A submitted manuscript is the version of the article upon submission and before peer-review. There can be important differences between the submitted version and the official published version of record.

People interested in the research are advised to contact the author for the final version of the publication, or visit the DOI to the publisher's website.

- The final author version and the galley proof are versions of the publication after peer review.

- The final published version features the final layout of the paper including the volume, issue and page numbers.

Link to publication

\footnotetext{
General rights rights.

- You may freely distribute the URL identifying the publication in the public portal. please follow below link for the End User Agreement:

www.umlib.nl/taverne-license

Take down policy

If you believe that this document breaches copyright please contact us at:

repository@maastrichtuniversity.nl

providing details and we will investigate your claim.
}

Copyright and moral rights for the publications made accessible in the public portal are retained by the authors and/or other copyright owners and it is a condition of accessing publications that users recognise and abide by the legal requirements associated with these

- Users may download and print one copy of any publication from the public portal for the purpose of private study or research.

- You may not further distribute the material or use it for any profit-making activity or commercial gain

If the publication is distributed under the terms of Article $25 \mathrm{fa}$ of the Dutch Copyright Act, indicated by the "Taverne" license above, 
Sylvia Heuchemer, Stefanie Kleimeier, Harald Sander

The Geography of European Cross-Border Banking: The Impact of Cultural and Political Factors

$\mathrm{RM} / 08 / 008$

JEL code: C21, F34, F36, K20, Z10

\section{METE@R}

Maastricht research school of Economics of TEchnology and ORganizations

Universiteit Maastricht

Faculty of Economics and Business Administration P.O. Box 616

NL - 6200 MD Maastricht

phone : ++31433883830

fax : ++31433884873 
Working Paper Version: April 24, 2008

\title{
The Geography of European Cross-Border Banking: The Impact of Cultural and Political Factors
}

by

Sylvia Heuchemer ${ }^{\mathrm{a},}$, Stefanie Kleimeier ${ }^{\mathrm{b}, \mathrm{c}}$ and Harald Sander ${ }^{\mathrm{a}, \mathrm{c}}$

${ }^{a}$ Faculty of Economics and Business Administration, Cologne University of Applied Sciences Claudiusstr. 1, 50678 Köln, Germany

${ }^{b}$ Limburg Institute of Financial Economics, FdEWB, Maastricht University, Tongersestraat 53, 6211 LM Maastricht, The Netherlands.

${ }^{c}$ METEOR, Maastricht University, Tongersestraat 53, 6211 LM Maastricht, The Netherlands.

\begin{abstract}
:
We investigate the determinants of European banking market integration with a focus on the potentially limiting role of cultural and political factors. Employing a unique data set of European cross-border loans and deposits, the study uses various gravity models that are augmented by societal proxies. While trade-theoretic reasoning can explain part of the surge in cross-border banking, we demonstrate that distance and borders still matter in the geography of European cross-border banking. Moreover, we can identify cultural differences and different legal family origin as important barriers to integration.
\end{abstract}

Keywords: cross-border loans, cross-border deposits, banking market integration, JEL Classification: $\quad$ C21, F34, F36, K20, Z10

* Corresponding author: Tel: +49-221-8275-3431, fax: +49-221-8275-3135, E-mail address: Sylvia.Heuchemer@fh-koeln.de (Sylvia Heuchemer). 


\section{$\underline{1 . \text { Introduction }}$}

In the recent years European financial market integration has made a big leap forward. Yet, retail banking is lagging far behind. Most researchers and practitioners agree that banking markets are still least integrated, regardless whether they base their assessment on quantity-based indicators such as cross-border loans and mergers and acquisitions (M\&As), price-based indicators such as interest rate convergence or new-based indicators such as reaction of the banking market to common shocks. ${ }^{1}$ Most recently, however, some quantitybased indicators such as cross-border M\&As reveal that banking market integration is gaining momentum - prompting some observers to conclude that the single European banking market is finally arriving (Schoenmaker and van Laecke 2006). Likewise, cross-border banking has been increasing rapidly, albeit starting from a very low base. Inside the euro zone crossborder loans have more than doubled from $€ 152$ billion (bn) in 1999 to $€ 361$ bn in 2006 while cross-border deposits have increased from $€ 221$ bn to $€ 316 \mathrm{bn}$, respectively. This paper takes a fresh look at these developments by exploring the determinants of cross-border banking in the euro zone by means of a gravity equation approach. This research strategy allows us to not only document the state and progress of integration, but also to identify important drivers of and barriers to banking market integration with a particular emphasis on the limiting role of cultural and political differences.

Tinbergen (1962) and Pöyhönen (1963) independently introduced the gravity equation framework for empirical analyses of bilateral trade and foreign investment. Since then it has been extensively and successfully applied to a larger number of policy issues such as the effect of regional integration, a common currency or trade policies. Most recently, researchers have started to expand the scope of the gravity equation framework by studying the role of political and cultural differences. (Flörkemeier 2002, Guiso et al. 2005, Heuchemer and

\footnotetext{
${ }^{1}$ Baele et al. (2004) suggest this classification of the empirical literature on financial integration. For a recent overview of the evidence see Kleimeier and Sander (2007).
} 
Sander 2007, Kalemli-Ozcan and Sørensen 2007). Theses studies show that cultural differences, trust in others and confidence in institutions can be important drivers and barriers to economic exchange. Trust, culture and institutions might well be even more pertinent in cross-border banking. Berger (2003: 460), summarizing the findings of a well-known study on the globalization of the banking industry (Berger et al. 2003), concludes "that foreign banking organizations may be at significant competitive disadvantage in providing price, quality, and mix of services that best suit bank customers, and that such disadvantages may limit the integration of the banking industry" (italics are ours).

To our knowledge no study has yet investigated the role of cultural and political affinities in European retail banking in a gravity model setting. The authors have been granted access to a set of bilateral loan and deposit volume data for the time period 1999 to 2006 which for the first time allows the (panel) estimation of a gravity model for cross-border banking. We begin our investigation by developing a baseline gravity model. This model starts with the classical Newton-inspired variables, economic size (as indicator for masses) and distance, and is then augmented to explore the basic determinants of the trade structure in the light of trade theory. Such augmentation captures the effects of comparative advantage (the "old" trade theory) as well as the role of product differentiation and economies of scale (the "new" trade theory). This baseline model is subsequently used to explore the impact of political and cultural factors on cross-border banking. For this reason we have collected a large number of political and cultural proxies. We consider a variety of specifications, including least square dummy variables (LSDV), fixed effects and dynamic panel estimation in order to obtain the best possible estimation.

Our baseline gravity model suggests that the direction of cross-border banking can be explained by the economic size of the trading partners as well as by comparative advantages in financial sector development and product heterogeneity as suggested by the "new trade theory". Moreover, as it is well documented for merchandise trade, we can show that distance 
and borders also matter considerably for cross-border banking. However, specification tests as well as theoretical considerations suggest the presence of strong country-pair fixed effects. Unfortunately, including country-pair fixed effects eliminates just these coefficients as well as those of other relatively time-invariant cultural and political variables that we are interested in. Our innovation to overcome this problem is to replace country-pair fixed effects by country-pair specific economic, cultural and political variables defined as country differences and measured as Euclidean distances between the individual values. In fact, cross-border banking, just like all international transactions, must be viewed as a response to differences that call for arbitrage processes. These variables are successively included into our LSDV model. Doing so, the importance of distance and borders as well as the trade-theoretic conclusion mentioned before remain robust. This model is then augmented for political and cultural factors. We find relatively little evidence for the importance of political factors and can demonstrate that cultural differences are a more important barrier to cross-border banking than differences in "governance". In particular we single out differences in trust levels and legal system heritage as cultural barriers to cross-border banking.

The plan of the paper is as follows. Section 2 describes the methodology of our gravity modeling approach. Section 3 gives a detailed description of the data with a special reference to our measurement of cultural and political differences. Section 4 reports the results. Section 5 concludes. 


\section{Methodology}

We examine European banking market integration by analyzing the determinants of bilateral cross-border loans and deposits in the euro zone for the period 1999 to 2006 by means of a gravity model. Gravity equations have become the workhorse for analyzing bilateral trade flows and are arguably the best and most popular way to study the impact of third factors on trade, such as political, cultural and legal differences. The basic version of a gravity model explains trade flows between a pair of countries as a function of their respective economic masses (GDP) and the square of the geographical distance (DISTANCE) separating them. The model is completed by the gravitational constant $(\mathrm{G})$ :

(1a) $\mathrm{X}_{\mathrm{ijt}}=\mathrm{G} \cdot \frac{\mathrm{GDP}_{\mathrm{it}} \cdot \mathrm{GDP}_{\mathrm{jt}}}{\left(\operatorname{DISTANCE}_{\mathrm{ij}}\right)^{2}}$

where $\mathrm{X}_{\mathrm{ijt}}$ denotes bilateral exports of country $\mathrm{i}$ to country $\mathrm{j}$ in year $\mathrm{t}$. In order to obtain a linear relationship between the trade flows and the explanatory variables, the equation is converted into a logarithmic version:

$$
\ln \left(\mathrm{X}_{\mathrm{ijt}}\right)=\alpha_{0}+\beta_{1} \ln \mathrm{GDP}_{\mathrm{it}}+\beta_{2} \ln \mathrm{GDP}_{\mathrm{jt}}+\beta_{3} \ln \operatorname{DISTANCE}_{\mathrm{ij}}
$$

Geographical distance is considered to be a proxy of all bilateral transaction costs, ranging from pure transportation and information costs to hidden transaction costs like cultural or political differences. Since geographical distance can only be a rough measure of all different frictions in international trade the basic gravity model is usually been augmented by various factors such as to capture natural barriers (common border), political barriers (trade agreements, currency unions, etc.) and cultural barriers (common language, etc.). ${ }^{2}$

Even though gravity models are able to explain more than half of the variation in international trade, they were considered for a long time as pure physical analogues without any theoretical foundation. Since Anderson (1979), who was the first to provide a micro foundation, many efforts have been put in the theoretical foundation of gravity models (e.g. 
Bergstrand 1985, 1989, Deardorff 1998, Anderson and van Wincoop 2003). In response to the theoretical foundation the naïve version of the gravity model has been improved steadily and adopted to the different trade theories. A popular version in the empirical trade literature (see Baltagi et al. 2003) is:

$$
\begin{aligned}
\ln \mathrm{X}_{\mathrm{ijt}}= & \alpha_{0}+\beta_{1} \operatorname{lnSIZE_{\mathrm {ijt}}}+\beta_{2} \ln \operatorname{REL}_{\mathrm{ijt}}+\beta_{3} \ln \operatorname{SIMILAR}_{\mathrm{ijt}}+\beta_{4} \ln \operatorname{DISTANCE}_{\mathrm{ij}} \\
& +\beta_{5} \text { BORDER }_{\mathrm{ij}}+\sum_{\mathrm{k}=6}^{\mathrm{K}} \beta_{\mathrm{k}} \ln \mathrm{Y}_{\mathrm{ijt}}+\mathrm{u}_{\mathrm{ijt}}
\end{aligned}
$$

with:

$$
\begin{aligned}
& \operatorname{SIZE}_{\mathrm{ijt}}=\ln \left(\mathrm{GDP}_{\mathrm{it}}+\mathrm{GDP}_{\mathrm{jt}}\right) \\
& \mathrm{REL}_{\mathrm{ijt}}=\left|\ln \left(\frac{\mathrm{GDP}_{\mathrm{it}}}{\mathrm{POP}_{\mathrm{it}}}\right)-\ln \left(\frac{\mathrm{GDP}_{\mathrm{jt}}}{\mathrm{POP}_{\mathrm{jt}}}\right)\right| \\
& \text { SIMILAR }_{\mathrm{ijt}}=\ln \left[1-\left(\frac{\mathrm{GDP}_{\mathrm{it}}}{\mathrm{GDP}_{\mathrm{it}}+\mathrm{GDP}_{\mathrm{jt}}}\right)^{2}-\left(\frac{\mathrm{GDP}_{\mathrm{jt}}}{\mathrm{GDP}_{\mathrm{it}}+\mathrm{GDP}_{\mathrm{jt}}}\right)^{2}\right]
\end{aligned}
$$

The variables SIZE, REL and SIMILAR are motivated by the recent advances of trade theory as suggested by Helpman and Krugman (1985) and Krugman (1980). SIZE is a measure of the economic masses and either defined as the product or the sum of the GDPs of the trading partners. ${ }^{3}$ The so-called new trade theory considers the coefficient $\beta_{1}$ to be positive as a larger economic mass is expected to lead to more trade particularly in form of intra-industry trade under the conditions of heterogeneous products and economies of scale. REL measures the differences in GDP per capita as a proxy for relative factor endowments. Thus a positive coefficient for $\beta_{2}$ indicates that bilateral trade is inter-industry and driven by comparative advantage as suggested by the "old" trade theory of the Ricardo-Heckscher-Ohlin-Samuelson type. In contrast, a negative value for $\beta_{2}$ would indicate support for the Linder hypothesis

\footnotetext{
${ }^{2}$ See e. g. Baxter and Kouparitsas (2006).

${ }^{3}$ A strict interpretation in the sense of Newton would demand to calculate SIZE as the product of the GDPs. Many empirical papers use however the (log of) the sum of the GDPs (e.g. Baltagi et al. 2003). This proxy allows an easier direct interpretation of the coefficients as the elasticity of bilateral trade with respect to their joint GDP.
} 
which suggests that trade volumes are larger the more similar the trading partners are in terms of factor proportions and thus development. Finally, the new trade theory hypothesizes that trade is the higher the more similar the countries are. This latter point is additionally investigated by using the variable SIMILAR which is defined as a similarity index of two trading partners' GDP and used to measures the relative country size. The variable increases in value with more similarity and is defined in a range from 0 to 0.5 . A positive value of $\beta_{3}$ would therefore indicate that increased similarity would lead to more trade and also thus support the new trade theory hypothesis.

However, since our analysis focuses only on a single good, bilateral loans or bilateral deposits, we have to take into account that these bilateral transactions may possibly be less sensitive to overall economic conditions as indicated by their GDPs or per-capita GDPs but more influenced by national banking market conditions. We thus adjust the gravity model also to banking market analysis. We retain SIZE as an indicator of relative masses, but use an indicator for relative financial development (REL_X) and of the overall similarity of the size of the financial sector (SIMILAR_X). There is some debate on how financial development is best been measured, for example as a ratio of broad money (MO) to GDP, deposits (DE) to GDP or private credit (CRE) to GDP ${ }^{4}$. Consequently our SIMILAR- and REL-variables are defined as follows with "X" being proxied by "MO", "DE" or "CRE", respectively:

$$
\mathrm{REL}_{-} \mathrm{X}_{\mathrm{ijt}}=\left|\ln \left(\frac{\mathrm{X}_{\mathrm{it}}}{\mathrm{GDP}_{\mathrm{it}}}\right)-\ln \left(\frac{\mathrm{X}_{\mathrm{jt}}}{\mathrm{GDP}_{\mathrm{jt}}}\right)\right|
$$

$$
\text { SIMILAR_ }_{\mathrm{ijt}_{\mathrm{jt}}}=\ln \left[1-\left(\frac{\mathrm{X}_{\mathrm{it}}}{\mathrm{X}_{\mathrm{it}}+\mathrm{X}_{\mathrm{jt}}}\right)^{2}-\left(\frac{\mathrm{X}_{\mathrm{jt}}}{\mathrm{X}_{\mathrm{it}}+\mathrm{X}_{\mathrm{jt}}}\right)^{2}\right]
$$

Since transportation as well as information costs play an important and restricting role in international exchange, DISTANCE, typically measured as the great circle distance in kilometers between two countries' capital cities, is regularly included as a proxy for bilateral

\footnotetext{
${ }^{4}$ For a discussion in the context of the finance-and-growth literature see e.g. Wachtel 2003.
} 
trading costs. In line with the traditional gravity approach, $\beta_{4}$ is therefore expected to be negative. Because distance is only an imperfect measure of transaction costs, BORDER is often added as second proxy of trading cost and is measured as 1 if two countries share a common border and 0 otherwise. As common borders are expected to boost bilateral trade, $\beta_{4}$ should be positive. In order to control for further different frictions in international trade, the gravity model is finally augmented by various factors as e.g. cultural and political similarities, $\mathrm{Y}_{\mathrm{ijt} \text {. }}$

In principle, our baseline model (2) could be estimated by OLS. However, the estimation results are possibly biased due to omitted variable effects. These could reflect effects that are (i) common to all country-pairs but specific to any year $t$ and (ii) effects that are country-pair specific but common to all years respectively. We therefore apply panel data techniques and define the error term $\mathrm{u}_{\mathrm{ijt}}$ as follows:

$$
\mathrm{u}_{\mathrm{ijt}}=\lambda_{\mathrm{ij}}+\tau_{\mathrm{t}}+\varepsilon_{\mathrm{ijt}}
$$

with $\tau_{\mathrm{t}}$ capturing time effects and $\lambda_{\mathrm{ij}}$ reflecting any time-invariant bilateral idiosyncratic effect. These unobserved effects may be considered as fixed or random. Since our sample consists of almost all countries that have introduced the euro as their common currency, we cannot treat our sample as a random draw from a large population. Therefore we hypothesize that it is best to consider $\lambda_{\mathrm{ij}}$ as a separate intercept to be estimated for each country-pair. Because all countries belong to the euro zone, we also see the time effect as fixed, capturing economic shocks or changes in macroeconomic environment. In addition, year-specific effects may account for important regulatory and behavioral changes in the first years of the currency union. In order to substantiate our priors in favor of a fixed effects model we also estimate random effects models and run different Hausman tests.

Next to the static version of our fixed effect baseline model, we also estimate a dynamic specification, thus abandoning the assumption that the $\varepsilon_{\mathrm{ijt}}$ are not serially correlated, since it may be likely that the current level of loans or deposits may depend on the previous 
levels. In fact, habit persistence may be very likely in banking, which is often characterized by high switching and information costs. Therefore we include the lagged-dependent variable as an additional explanatory variable in our model. However, since the lagged-dependent variable is correlated with the country-pair effects and therefore with the error term, the estimators are biased. In order to deal with this problem we use instrumental variables and estimate by means of the generalized methods of moments (GMM) following Arellano and Bond (1991). Based on the estimation of the static and the dynamic fixed effects model we try to identify the best baseline model which should thus inform us correctly about the impact of the trade-theoretic variables in explaining cross-border banking.

The fixed effects approaches, however, come at the cost of not being able to estimate the impact of time-invariant determinants such as DISTANCE, BORDER or the cultural factors that we are especially interested in. In addition, country-pair fixed effects control only for bilateral trade resistance, e.g. the barriers to trade between two countries. In order to estimate a gravity model appropriately it is also essential to analyze not just bilateral trade resistance but also multilateral trade resistance, i.e. the barriers to trade that each country faces with all its trading partners. A widely used approach in literature to deal with multilateral resistance is to use country dummies (see e.g. Anderson and van Wincoop 2003, Baldwin and Taglioni 2006). ${ }^{5}$ This approach has also the advantage of controlling for incomplete homogenization of the bilateral loan and deposit data. We therefore will finally use a least square dummy variable (LSDV) estimation approach that controls only for bank countries $\left(\delta_{\mathrm{i}}\right)$ and bank-customer countries $\left(\gamma_{\mathrm{j}}\right)$, but exclude country-pair idiosyncratic effects. We then define the error term $u_{i j t}$ as ${ }^{6}$ :

$$
\mathrm{u}_{\mathrm{ijt}}=\delta_{\mathrm{i}}+\gamma_{\mathrm{j}}+\tau_{\mathrm{t}}+\varepsilon_{\mathrm{ijt}}
$$

\footnotetext{
${ }^{5}$ According to the theoretical derivation of Feenstra (2002) and Anderson and van Wincoop (2004), the country fixed effects reflect also prices.

${ }^{6}$ Since we are primarily interested in estimation the influence of the time-invariant determinants we focus on the static approach and assume that the $\varepsilon_{\mathrm{ijt}}$ are not serially correlated.
} 
Unfortunately, the exclusion of country-pair idiosyncratic effects is also not without cost because the country-specific effects are not able to account for specific bilateral factors so that the omitted variable bias is still an issue. ${ }^{7}$ Our innovation to the literature here is to model country-pair-specific differences. The reasons are theoretical and methodological. With respect to the latter, we strive to keep the omitted variable bias as small as possible. Theoretically, cross-border banking makes only sense and should thus respond to "differences" which call for cross-border arbitrage. We distinguish and investigate the impact of a large number of county-pair specific differences, most - but not all - of them measured by means of non-time varying variables which proxy political and cultural differences. In order to create country-pair specific measures of these variable to substitute for the countrypair specific effects we first measure each of our cultural and political proxies on a country(and if possible year-) specific level and then calculate Euclidean distances between two countries for a set of variables as:

$$
\mathrm{ED}_{\mathrm{ijt}}=\sqrt{\sum_{\mathrm{k}=1}^{\mathrm{K}}\left(\mathrm{V}_{\mathrm{itk}}-\mathrm{V}_{\mathrm{jtk}}\right)^{2}}
$$

where ED is the Euclidean distance and $\mathrm{V}$ are the different variables that are taken into account.

Our modeling strategy is thus as follows: First we develop a baseline gravity model employing both, the pure trade-theoretic explanatory variable (3) to (5) as well as the financial development adjusted variables (4') and (5') using the various measures of financial development. Secondly, we test these models for fixed, random and dynamic panel effects and with then, thirdly, select the most appropriate model. Finally, based on the specification of this "best model", we try to identify the impact of non-time varying cultural and political differences by augmenting a LSDV approach by bilateral factors measured as Euclidean distances as well as other factor when appropriate.

\footnotetext{
${ }^{7}$ See Baldwin and Taglioni (2006).
} 


\section{$\underline{\text { 3. Data }}$}

As independent variables we use central-bank data on outstanding cross-border loans and deposits. Cross-border banking data are typically either aggregated to show the position of a single country's banks vis-à-vis all foreign borrowers or depositors or to show net foreign claims. In contrast, our data are disaggregated so that we are able (1) to distinguish crossborder loans from deposits and (2) to identify banks' as well as customers' residence. Thus, our set of bilateral data allows us to analyze cross-border banking between the EMU membercountries Austria, Belgium, Finland, France, Germany, Greece, Ireland, Italy, Luxembourg, Netherlands, Portugal and Spain. ${ }^{8}$. We observe volumes of outstanding loans and deposits on a quarterly basis from 1999 to 2006 and are thus able to include a time-dimension in our analysis. As most of our proxies for potential driving forces of cross-border finance are only measurable on an annual basis we convert the quarterly volumes into annual ones by calculating simple averages over the four quarters. In sum, our unit of observation is defined as the outstanding volume of loans between banks of country $i$ to borrowers of country $j$ in year $\mathrm{t}\left(\right.$ BILOANS $\left._{\mathrm{ijt}}\right)$. Correspondingly, BIDEPOSITS $\mathrm{ijt}_{\mathrm{jt}}$ defines the outstanding volume of deposits from depositors of country $i$ to banks of country $j$ in year $t$. A first impression of the dynamics of European cross-border lending can be gained from Panel A of Table 1. Between 1999 and 2006, the total amount of outstanding cross-border loans more than doubled from $€$ 152 bn to $€ 361$ bn. Annual growth rates, ranging from $3.4 \%$ to $20.1 \%$, are not only substantial but exceed growth rates for domestic loans in the Eurozone by a factor 1.7 (for 2000) up to 2.6 (for 2005). The only year in which cross-border loans are slightly slower at $3.4 \%$ versus $4.1 \%$ domestically is 2002 . For the average (median) country in the euro zone, cross-border loans rose from $€ 1,747 \mathrm{~m}$ to $€ 3,341 \mathrm{~m}(€ 854 \mathrm{~m}$ to $€ 1,304 \mathrm{~m})$ in nominal terms indicating an overall increase in banking market integration. However, when we compare the

\footnotetext{
${ }^{8}$ Data on cross-border loans made by and cross-border deposits received by banks in Luxembourg and Portugal are not disclosed. However, cross-border loans made to borrowers in Luxembourg and Portugal as well as crossborder deposits made by depositors from Luxembourg and Portugal are known.
} 
average and median country over time we can observe that the distribution of cross-border loan granting is still highly right-skewed, indicating that the lending activities are obviously concentrated in a few countries. A look at cross-border lending relative to GDP of either the bank or customer country, however, provides a more differentiated impression of the dynamics of cross-border activities: Lending appears to be stable except when looking at the average (rather than median) country and when measuring cross-border loans in percent of customer-country GDP. This leads us to conclude that only some but not all customer countries benefited from increased banking market integration in form of more cross-border loans. Furthermore, cross-border loans are more important in terms of GDP in borrowercountries than in lender-countries indicating that funds flow predominantly from larger to smaller economies. Panel B of Table 1 presents the corresponding data for cross-border deposits and similar conclusions can be drawn. It is interesting to note that while the volume of cross-border deposits was higher that the volume of cross-border loans in 1999, that is no longer true in 2006. For the average cross-border deposit outstanding, the nominal increase from $€ 221$ bn to $€ 316$ bn actually represents a drop in cross-border deposits when measured in relation to customer-country GDP. As the median statistics reveal, deposit market integration only increased for some of the euro zone countries. This hypothesis is also corroborated when we compare the average and median country. The distribution of crossborder deposits is even more right-skewed than the distribution of cross-border loans. In contrast to domestic deposits, cross-border deposits seem to growth somewhat more slowly each year. The notable exception is 2006 when the growth rate of cross-border deposits was more than twice that of domestic deposits.

[Insert Table 1 about here] 
As we are particularly interested in investigating the role of cultural and political differences, we measure the impact of these factors as Euclidean distances. To arrive at them we collected a large number of such indicators. With respect to cultural proxies it is a common, though rather vague strategy to use a dummy variable for the existence of a common language (LANGUAGE). A more sophisticated, and in financial integration studies successfully applied ${ }^{9}$ dummy is based on La Porta et al. (1998) which identifies countries that belong to the same legal family (LEGALFAM). A third measure of culture is the extent to which citizens of one country trust those of another country. Guiso et al. (2005) use such a directly measured bilateral trust variable based on Eurobarometer surveys. While this variable would be particularly appealing for our analysis, the latest data available date back to 1996 . As Guiso et al. (2005) indicate, this variable is potentially endogenous, as more bilateral transactions are likely to breed more bilateral trust. We therefore conclude that this variable is unfortunately of no value for our analysis for the $1999-2006$ period. ${ }^{10}$ We thus had to search for alternatives. A first alternative is to use the overall trust level in a society. Such data are available from the World Value Survey and have also been used by Kalemli-Ozcan and Sørensen (2007) in a study to identify the limits to financial integration. While these authors are using the level of trust as a determinant, we will here focus at differences in trust level between countries pairs, thus highlighting the - in our view - more important cultural differences. We thus measure TRUST as the Euclidean distance in trust levels across countries. A second alternative to measure cultural differences could be derived from Hofstede's four cultural dimensions, a measure that figures prominently in the management literature. Based on the result of a broad questioning in more than 50 countries, Hofstede (1980) conducted a factor analysis to identify four different dimensions that can be used to

\footnotetext{
${ }^{9}$ See e.g. Cecchetti (1999) and Sander and Kleimeier (2004) who identify differences in legal family heritage as a factor limiting European monetary and financial integration.

${ }^{10}$ We nevertheless have tried this bilateral trust variable with the 1996 values in our gravity approach. However, no significant effects could be detected.
} 
describe national cultures. Power distance measures the extent to which the unequal distribution of power in organizations and institutions is accepted, individualism deals with the relationship of individuals with groups, masculinity expresses to which extend the distribution of roles between genders is predominant and uncertainty avoidance indicates a culture's tolerance to unknown, surprising situations. According to the results of Hofstede's factor analysis, each country can be characterized by a score on each of the four dimensions and these scores are the basis for our cultural proxy. Casson (2006) identifies as the four major dimensions of culture individualism, pragmatism, the level of tension and the degree of trust. He admits partial correspondence between his and Hofstede's cultural dimensions, except for power distance which may in his view better be replaced by degree of trust. For our study we therefore define three alternative measures of cultural distances: First, we calculate cultural distance as the Euclidean distance based on four cultural dimensions of Hofstede (CULTURE). Additionally we define cultural differences in line with Cassen (2006) and calculate the Euclidean distance for the Hofstede factors where power distance is replaced by trust (TRUST\&CULTURE3) and where the all Hofstede factors are augmented by trust (TRUST\&CULTURE4). To capture the impact of political factors, we utilize the six timevarying dimension of governance as defined by the World Bank: voice and accountability (VOICE), political stability and absence of violence (POLSTAB), government effectiveness (GOVEFF), regulatory quality (REGQAL), rule of law (LAW), and control of corruption (CORRUP) and calculate the Euclidean distance. In addition, we also aggregate all these dimensions into an overall political risk proxy (POL) that measures the general political dissimilarity between countries in one Euclidean distance.

Furthermore we also investigate the role of potentially explanatory time-variant economic variables such as bilateral trade (TRADEVOL) and foreign participation in the banking industry (FRGBNK). TRADEVOL is a bilateral variable per se. The role of FRGBNK is investigated for the bank country, for the customer country and also defined as a 
Euclidean Distance. Details regarding the exact measurement of and data sources for all our variables can be found in Table A1 of the Appendix.

\section{The Determinants of Cross-Border Loans in the Euro Zone}

\subsection{From Descriptive Statistics to the Baseline Gravity Model}

A first insight into the potential determinants of cross-border banking can be gained from studying the differences between country-pairs with a large versus small amount of cross-border loans and deposits (Table 2). Looking at the beginning and end of our sample period and comparing country-pairs which fall into the top versus bottom quartile with respect to cross-border loans and deposits reveals that larger economies fund as well as receive more cross-border loans and deposits. We therefore hypothesize the SIZE matters. Furthermore, high levels of cross-border banking are typically associated with higher financial development (here proxied by our favorite financial development measure, the credit-to-GDP-ratio) in both bank and customer countries, while the role of the trade-theoretic variables SIMILAR and REL is less clear-cut. Cross-border lending and cross-border bank-FDI appear to be substitutes as more cross-border lending takes place when the market share of foreign banks is low in the customer-country. The same is true for cross-border deposits. Finally, regarding our various geographic, cultural and political measures we find that cross-border banking is high for countries with a common border, common language, a common legal family, where differences in culture and trust are smaller and where political risks are more similar. Interestingly, the geographic reach of cross-border loans and deposits has increased over time as the increasing mean for DISTANCE indicates. Regarding the role of deposit insurance the picture is clearest at the end of the sample period whereas the results for the beginning of the sample period are mixed. In 2006, countries that attracted a larger volume of cross-border deposits tended to have a deposit insurance coverage superior to that in the customer's home country. 
[Insert Table 2 about here]

The starting point of our empirical analysis of the cross-border loans and deposits is equation (2) to which we apply panel data techniques that take into account country-pair and time specific effects. Thus the error term $u_{i j t}$ is defined as given in equation (6). As tradetheoretic variables we employ the traditional GDP-based definitions (3) to (5) as well as the financial development adjusted definitions (4') and (5') using the various financial development proxies. Regardless which definition of these variables is employed, the result of the Hausman test confirms the existence of fixed rather than random effects (see Table A2 in the Appendix). We thus continue with static and dynamic fixed effects estimates in order to determine the best baseline model. The full details of the estimates can be found in Table A3 in the Appendix, while we report our preferred regressions in Table 3.

In order to relate to the traditional trade-theoretic specification we start with the GDPbased definitions of the variables (3) to (5). Interestingly, this specification works to some extent for deposits but not loans. In the loan regressions, none of these explanatory variables are statistically significant, neither in the static nor in the dynamic estimation. However, in the static fixed effects model we obtain a high R-squared which is typical for gravity models. We therefore conclude that a bigger part of the variation in cross-border loans can be explained by factors that are country-pair and time specific. Moreover, the positive and highly significant coefficient for the lagged loans indicates that the data generating process is dynamic rather than static and that the cross-border lending is to some extent habit persistent. Finally, both the static and the dynamic fixed effects model perform better when time dummies are included. For that reason we conclude, that regulatory changes over the investigated period have an impact on cross-border loans. By contrast, cross-border depositing appears to be in line with a Ricardo-Heckscher-Ohlin-Samuelson explanation. Additionally, it can also be 
explained by new trade theory arguments as the SIZE variable is significant and positive. This is confirmed from both, the static and the dynamic model. However, for deposits the evidence in favor of a dynamic model is less clear as the autoregressive coefficient is only 0.42 with a t-value below 2, thus giving a hint that the static model may also be appropriate. In contrast to the loans estimates, the exclusion of time dummies leads to better results and we suppose that regulatory changes play a less important role in the case of cross-border deposits.

Given the relatively low explanatory power of the GDP-based proxies for trade determinants, especially in the case of cross-border loans, we hypothesize that cross border banking is possibly more influenced by national banking market conditions than by overall economic factors. Thus we investigate the role of relative development and similarity of the financial sector as defined in equation (4') and (5'). We conduct all fixed effects estimates by using all three financial development proxies. The general message from this exercise is firstly, that loans now clearly show habit persistence while deposits do not. This result holds regardless of which proxy for financial development is used. Our estimates thus confirm the theoretically plausible hypothesis that international depositors are more mobile then international borrowers. Secondly, when investigating the various proxies further by comparing parameter stability between the fixed effect and LSDV regression as well as by looking into the data properties of deposits and broad money, we clearly favor the credit proxy for the loan and the deposit regressions. ${ }^{11}$ Thirdly, the inclusion of time dummies in the dynamic loan regressions is methodologically no longer necessary. Probably, regulatory changes are already captured in our proxies. This is different for deposits where we reject the hypothesis of habit persistence and favor the static model with time dummies, which possibly reflect an impact of regulatory changes that is not captured by our financial development proxies.

\footnotetext{
${ }^{11}$ In addition, since the distribution of deposits is even more right-skewed than the distribution of credits, we prefer as an explanatory variable a variable based on credit. The same explanation holds for money, as deposits are part of the broad definition of money.
} 
The regression results are reported in Table 3. Our reference regression for loans is the dynamic model without time dummies. It shows a plausible 0.7 , though only marginally significant, elasticity of bilateral loans with respect to the sum of the partner GDPs. The implied (marginal) support for the financial variant of the new trade theory-hypothesis is reinforced by the positive and significant coefficient for SIMILAR_CRE, which indicates that country-pairs with a more similar financial sector are also having more bilateral loans. A financial comparative advantage hypothesis is not supported as financial development differences are not found to promote cross-border loans. With respect to deposits our reference model is the static fixed effects model with time dummies. Size matters, as indicated by highly significant GDP-elasticity of 2.5. As for cross-border loans, the coefficient is in line with the initial GDP-based estimation, though somewhat larger. This result together with the significant coefficient for SIMILAR lends strong support for a new trade theory explanation of cross-border deposits while the comparative advantage hypothesis is again clearly rejected.

In sum, loans seem to follow an autoregressive process while deposits do not. Differences in per-capita GDP appear to promote cross-border banking in the traditional way, but financial development matters too. Country-pairs with equally developed and sized financial markets have more bilateral cross-border banking activity, possibly indicating that customers search for variety rather than exploit financial development differences. Nevertheless, there is very strong evidence for country-pair fixed effects and we can conclude that the variation in cross-border banking can largely be explained by country-pair and/or time specific factors. This clearly indicates the important role of bilateral determinants such as e.g. geographical distance, common border, culture, trust, legal system origin etc. which unfortunately remain unexplored in a fixed effects model. Moreover, these country-pair fixed effects may also be responsible for the insignificance of the pair-wise defined trade-theoretic variables that show little variation over time. We conclude that the results of the fixed effects 
models suggest that country-pair specific factors are primarily important in explaining crossborder banking. Unfortunately, most of these factors are time-invariant and can thus not be investigated in a fixed effects model. Instead, we will now investigate these factors in LSDV model specifications that build on our fixed effects reference models for cross-border loans and deposits.

[Insert Table 3 about here]

\subsection{The Geography of Cross-Border Loans}

In order to identify the main driving or impeding forces, we next apply several LSDV specifications to the loan and deposit regression, respectively. In contrast to the static and dynamic panel approaches, we will model the country-pair effects separately as Euclidean distances in order to identify arbitrage and arbitrage impeding factors. Moreover, in order not to misread a general "multilateral resistance" to cross-border banking for bilateral resistance, we will in the following control for bank and customer specific effects by including country dummies. These dummies serve as a proxy for barriers to cross-border lending and depositing that each country's banks face with all their customers. Finally, the country dummies will also control for all unobserved country differences in regulation, taxation etc. as well as for differences in the data, which are not fully homogenized. In the following LSDV models the error term in equation (2) is therefore defined as indicated in equation (7).

The baseline version of the LSDV gravity model (Table 3, Panel A) already explains 83 percent of the variation of cross-border loans, regardless of whether the trade-variables are defined with GDP or credit proxies. However, the estimates with the credit proxies are the more promising ones in our view. Consequently we concentrate our description here on the estimation in the last two columns using credit as proxy. Economic SIZE has a positive impact and the elasticity is above one, signaling both an important role for intra-industry trade 
and a potential for an expanding share of cross-border banking in a growing euro zone. Likewise the positive and significant coefficient of SIMILAR lends also support for the new trade theory. However, our conclusion remains that comparative advantage still plays a role as countries with deeper credit market appear to grant more loans to countries with less liquid markets as can be interfered from the positive and significant coefficient of REL. Although the parameter estimates of the trade-theoretic variables are somewhat smaller than those found in typical merchandise trade estimations ${ }^{12}$, they indicate that cross-border loans may increasingly become an intra-industry phenomenon in the euro zone with product heterogeneity and economies of scale playing a bigger role.

As in merchandise trade, bilateral trading costs play an important role. The usual proxies, DISTANCE and BORDER are of significant influence. The coefficient for DISTANCE is with 0.59 somewhat lower than those regularly obtained for merchandise trade which are closer to one. Our estimate is however still substantial and clearly indicates the existence of an economic geography in cross-border lending. Likewise, a common border increase cross-border loans by $100 *(\exp (0.54)-1)=71.6 \%$. We then investigate the role of economic variables (see Table A5, Panel A in the Appendix) in promoting cross-border loans. An obvious candidate is bilateral trade. We can indeed establish that bilateral trade promotes bilateral loans. However, since trade is highly correlated with distance, the coefficient of the latter will then become insignificant. Moreover, as trade may also be correlated with other cultural variables as suggested by Guiso et al. (2005) we continue our investigation without the trade variable. ${ }^{13}$ We also investigate the role of foreign bank participation in cross-border loan granting. Here we find a small substitutive rather than complementary effect as the

\footnotetext{
${ }^{12}$ However, these results seem to be generally in line with the results Baltagi et al. (2003) have obtained from merchandise trade estimates when employing a similar model and using - like our model here - importer, exporter and time dummies.

${ }^{13}$ Table A5 in the Appendix provides all estimates of our LSDV reported in Table A3 with an additional trade volume variable included. The results are by and large comparable to the model without the trade variable except for the insignificance of DISTANCE.
} 
presence of foreign banks in the borrowers' countries reduces the amount of imported foreign loans (Table A4, Panel A in the Appendix, Reg 2 and 3).

The strong presence of country-pair fixed effects, however, warrants further investigation as such effects point to country-pair specific differences as potential barriers to cross-border loans. We have therefore defined all political and cultural variables as well as the foreign bank penetration variable as Euclidean distances. We first report their role when adding them alone to the baseline model (Table A4, Panel A in the Appendix, Reg 4 to 17) and then include cumulative in the order of statistical significance (Table A4, Panel A in the Appendix, Reg 18 to 20). A language dummy (LANGUAGE) usually measures cultural differences. We tried this dummy but found it less convincing (i.e. insignificant) compared to the alternative and richer cultural variables. For cultural variables we use the Hofstede variable CULTURE, the modified Hofstede variables (TRUST\&CULTURE3, TRUST\&CULTURE4), the "distance-of-trust-level” variable TRUST and the legal family origin variable (LEGALFAM). All culture proxies have a significantly limiting impact on cross-border loans. LEGALFAM origin has the most significant impact, followed by TRUST and the Hofstede variable and its modification. Replacing the power distance dimension by trust does not improve the estimation while adding TRUST to CULTURE yield a marginal improvement. However, TRUST and LEGALFAM are the most significant cultural variables. We favor them for two additional reasons: First they are easy and reliable to measure and second they cover independent, important straits of cultural differences. This is not true for the Hofstede variable and its variation which is highly correlated with legal origin and will loose all its explanatory power when used together with LEGALFAM (see Table A4, Panel A in the Appendix, Reg 18). The governance indicators are, however, not very successful in explaining cross-border loans, regardless whether they are introduced separately or as an overall political risk variable. There is only some evidence that differences in "regulatory 
quality" will reduce cross border loans while "voice and accountability"-differences will promote them.

Adding the significant variables increases the goodness of fit while the coefficients of the baseline equation remain remarkably stable. Our preferred gravity estimation is reported in Table 3, Panel A: The elasticity of cross-border loans with respect to economic SIZE is now slightly below 1 and more in line with the estimates for merchandise trade. A common BORDER is estimated to increase trade by $61.6 \%$ instead of $71.6 \%$ in the baseline model. Explained cultural proximity may account for this difference. A similar TRUST level across countries, a similar degree of foreign bank penetration (FRGBNK) and larger differences in voice and accountability (VOICE) all increase cross-border loans. Finally, belonging to the same legal family system (LEGALFAM) increases cross-border loans by $73.3 \%$. Thus, the evidence suggests that cultural (rather the governance) factors may continue to play an important limiting role in European Banking market integration.

\subsection{The Geography of Cross-Border Deposits}

In the following we again concentrate on our favorite regressions in the last two columns using the credit proxy for the trade-theoretic variables. Similar to our loan regression, the baseline version of the LSDV gravity model for deposits (Table 3, Panel B) already explains 83 percent of the variation of cross-border deposits. Economic SIZE has a positive impact and the elasticity is far above one, just signaling an even more important role for intra-industry trade and even larger potential for an expanding share of cross-border deposit taking in a growing euro zone. Likewise the positive and significant coefficient of SIMILAR lends support for the new trade theory. If we accept that a deep credit market is a good indicator of financial development, the evidence here speaks against a positive role of comparative advantage in cross-border deposit taking. The evidence strongly favors the new 
trade theory and indicates that cross-border deposit taking may increasingly be driven by product heterogeneity and eventually by economies of scale.

As in cross-border loans, bilateral trading costs play an important role. The usual proxies, DISTANCE and BORDER are even more important for deposits than for loans. The coefficient for DISTANCE is with 0.75 higher than the corresponding number in our loan regression, indicating the existence of even stronger geographical effects in deposit markets. Likewise, also a common BORDER is more important for deposits than for loans. With respect to the role of bilateral TRADEVOL in promoting cross-border deposits we find a positive, though less pronounced role than for loans. Again, since trade is highly correlated with DISTANCE and BORDER, the coefficients of the latter are now much smaller, but unlike in the loan regression they remain statistically significant, suggesting that cross-border deposits are more independent from trade and do lead a more pronounced "own arbitrage life".

When adding further economic, cultural and political variables we continue with the specification without the trade variable for reason of comparability and report our preferred LSDV estimation in Table 3, Panel B, column $4 .{ }^{14}$ The role of foreign bank penetration FRGBNK for cross-border deposits is now clearly a country-pair affair, rather than an issue of internationalization of the banking sector in the bank or customer country as such. In contrast to loans, more similar levels of banking market internationalization will lead to more crossborder depositing activity. This result seems to be very much in line with the trade-theoretic implications of the baseline version. To model cultural differences by means of a LANGUAGE dummy is more convincing here than for loans, yet not significant at conventional levels. Moreover, the Hofstede variable and its variation perform poorly for deposits and are insignificant at conventional level, though still carrying the expected (negative) sign. Again differences in TRUST levels and a common legal origin 
(LEGALFAM) are the relevant cultural variables, though trust level differences are less important than for loans while belonging to the same legal family is more important for deposit that for loans. In fact, belonging to the same legal family more than doubles crossborder deposits $(100 *(\exp (0.71)-1)=103.3 \%)$. With respect to political factors differences in political stability (POLSTAB) seem to lead to more cross-border depositing activity while differences in regulatory quality (REGQAL) inhibits cross-border depositing. However, using both variables in one regression results in an insignificant impact of regulatory quality differences. Finally the extent and differences in deposit insurance can be another major driver or limit of cross-border depositing. Deposit insurance coverage in euros matters in such a way that deposits flow when coverage is very different i.e. higher in the bank's country than in the customer's country (see the regression result for COVERAGE $\mathrm{ED}_{\mathrm{D}}$ in Panel B of Table A4 of the Appendix). This result is however only marginally significant, which might be explained by the fact that in several countries the regulatory coverage is extended voluntarily by banks or that many depositors move amounts abroad that are larger than the maximum amount covered by law. A stronger indicator is the fact whether the regulatory deposit insurance coverage is per deposit or only per depositor. Here, our results for DEPINSURE strongly indicate that customers move their deposits across the border if this allows them to shift from a depositor-based to a deposit-based coverage.

In sum, we arrive at our preferred gravity estimation for deposits that is both comparable to the loan model estimation as well as differing to it in a plausible way. First, cross-border deposits show a higher (joint) income elasticity than loans, standing at about 1.57. Secondly, diversification in similarly financially developed and internationalized banking system is an important driver of cross-border deposits, not differences and comparative advantage. Thirdly, geography is highly important with a common border propelling cross-border deposits by $100 *(\exp (0.63)-1)=87.8 \%$. Fourth, deeply rooted

\footnotetext{
${ }^{14}$ The regression results with TRADEVOL are reported in Table A5, Panel B in the Appendix.
} 
differences matter for limiting cross-border depositing as clearly indicated by the overwhelming impact of legal system origin. However, favorable deposit insurance systems can, as expected, help to increase the level of received cross-border deposits. In sum, convergence of financial system are helpful to increase cross-border depositing, but economic geography and culture still sets strong limits to integration deposit markets.

\subsection{Robustness of the Results}

As our prime interest is in estimating the impact of cultural, political and other limiting factors on cross-border banking we crosscheck the sensitivity of our analysis to various specifications. In particular we investigate to what extent the use of the trade-theoretic variables or the credit proxy has an impact on the estimated coefficients and whether a specification which includes the merchandise trade volume alters the results. The simple and very clear answer is that the estimates of the coefficients are rather stable across all specifications as can be seen from Table 4 .

\section{Insert Table 4 here}

\section{$\underline{\text { 5. Conclusions }}$}

Cross-border banking in the euro zone is still exhibiting a clear economic geography. In fact, the evidence clearly points to country-pair specific determinants of cross-border banking. One innovation in this paper is to model country differences as Euclidean distances and investigating their quantitative impact. This way we show that not only distance and border effects, but also cultural differences and legal heritage differences are important in shaping the bilateral pattern of cross-border banking and may well continue to exercise a limiting impact on banking market integration in the coming years. In this context it is interesting to note that differences in governance are of much less importance. A second 
innovation of our paper is to modify the trade-theoretic formulated gravity model to allow for financial development effects. While the trade-theoretic formulation reveals a certain crossborder-banking promoting role of differences in factor endowments, the modified version clearly indicates that cross-border banking is mainly promoted by similarity of financial systems rather than financial development differences. This effect is more pronounced in cross-border deposits than in cross-border loans. The latter clearly show habit persistence while the former do not. Moreover, when controlling for dynamic effects and financial development, we find significant time effects only for cross-border deposits but not for loans. This suggests that regulatory efforts towards a deeper integration of banking markets have been more successful in deposits than in loan markets. 


\section{$\underline{\text { References }}$}

Anderson, J., 1979. A theoretical foundation for the gravity equation. American Economic Review 69, 108-116.

Anderson, J., van Wincoop, E., 2004. Trade costs. Journal of Economic Literature 42, 691751.

Anderson, J., van Wincoop, E., 2003. Gravity with gravitas: A solution to the border puzzle. American Economic Review 93, 170-192.

Arellano, M., Bond, S., 1991. Some tests of specification for panel data: Monte Carlo evidence and an application to employment equations. Review of Economic Studies 58(2), 277-297.

Baele, L., Ferrando, A., Hördahl, P., Krylova, E., Monnet, C., 2004. Measuring financial integration in the euro area. Oxford Review of Economic Policy, 20(4). 509-530.

Baldwin, R., Taglioni, D., 2006. Gravity for dummies and dummies for gravity equations. NBER Working Paper No. 12516.

Baltagi, B.H., Egger, P., Pfaffermayr, M., 2003. A generalized design for bilateral trade flow models. Economics Letters 80, 391-397.

Baxter, M., Kouparitsas, M., 2006. What determines bilateral trade flows? NBER Working Paper No. 12188.

Berger, A., 2003. Global integration in the banking industry. Federal Reserve Bulletin, November, 451-460,

Berger, A., Dai, Q., Ongena, S., Smith, D.C., 2003. To what extent will the banking industry be globalized? A study of bank nationality and reach in 20 European Nations. Journal of Banking and Finance, 27(March). 383-415.

Bergstrand, J., 1985. The gravity equation in international trade: Some microeconomic foundations and empirical evidence. Review of Economics and Statistics 67, 474-481.

Bergstrand, J., 1989. The generalized gravity equation. Monopolistic competition, and the factor proportions theory in international trade. Review of Economics and Statistics 71, 143-153.

Casson, M. 2006. Culture and Economic Performance. In: Ginsburgh V.A. and Throsby, D., Handbook of the Economics of Arts and Culture. Elsevier: North Holland. 359-397.

Cecchetti, S.G., 1999. Legal structure, financial structure, and the monetary transmission mechanism. Federal Reserve Bank of New York Economic Policy Review, 5, 9-28.

Deardorff, A., 1998. Determinants of bilateral trade: Does gravity work in a neoclassical world? In Frankel, J. (ed. 1998), "The Regionalization of the World Economy", University of Chicago Press, 7-28.

European Central Bank, 2006. EU Banking Structure. European Central Bank, Frankfurt, October.

European Central Bank, 2004. Report on EU Banking Structure. European Central Bank, Frankfurt, November.

Feenstra, R., 1998. Integration of trade and disintegration of production in the global economy. Journal of Economic Perspectives, Fall, 31-50.

Feenstra, R. 2002. Border effects and the gravity equations: consistent methods for estimation. Scottish Journal of Political Economy 49, 491-506.

Flörkemeier, H., 2002. Limits to globalization? The regional pattern of world trade. INFER Discussion Paper No. 6.

Guiso, L., Sapienza, P. and Zingales, L., 2005. Cultural Biases in Economic Exchange, NBER Working Paper No. W11005.

Helpman, E., Krugman, P.R., 1985. Market structure and foreign trade: Increasing returns, imperfect competition and the international economy. MIT Press, Cambridge, MA. 
Heuchemer, S., Sander, H., 2007. Do cultural affinities influence international trade?, Paper presented on the 8th Annual International Business Research Conference of the University of North Florida and the University Warsaw, Jacksonville February 9-10.

Hofstede, G. 1980. Culture's Consequences. International Differences in Work-Related Values", Sage.

Kalemli-Ozcan, S., Sørensen, B.E., 2007. How integrated are European financial markets? And what's trust got to do with it? VOX Research-based policy analysis and commentary from Europe's leading economists, 28 November 2007, available at http://www.voxeu.org/index.php?q=node/751

Kleimeier, S., Sander, H., 2007. Integrating Europe's banking market. Where do we stand? Center for European Policy Studies Research Report on Finance and Banking. Brussels.

Krugman, P.R., 1980. Scale economies, product differentiation, and the pattern of trade. American Economic Review 70, 950-959.

La Porta, R., Lopez-de-Silane, F., Shleifer, A., Vishny, R.W., 1998. Law and Finance. Journal of Political Economy 106(6), 1113-1155.

Pöyhönen, P., 1963. A tentative model for the volume of trade between countries. Weltwirtschaftliches Archiv 90(1), 93-100.

Sander, H., Kleimeier, S. 2004. Convergence in euro-zone retail banking? What interest rate pass-through tells us about monetary policy transmission, competition and integration. Journal of International Money and Finance, 23, 461-492.

Schoenmaker, D., van Laecke, C., 2006. Current state of cross-border banking. Paper presented at the International Banking Conference "International Financial Stability: Cross-Border Banking and National Regulation. Federal Reserve Bank of Chicago, 56 October.

Tinbergen, J., 1962. Shaping the world economy: Suggestions for an international economic policy. New York: The Twentieth Century Fund.

Wachtel, P., 2003. How much do we really know about growth and finance? Federal Reserve Bank of Atlanta Economic Review, First Quarter, 34-47.

$\underline{\text { Appendix }}$

[Insert Tables A1 to A6 here] 
Table 1: The growth of bilateral cross-border banking in the euro zone over time

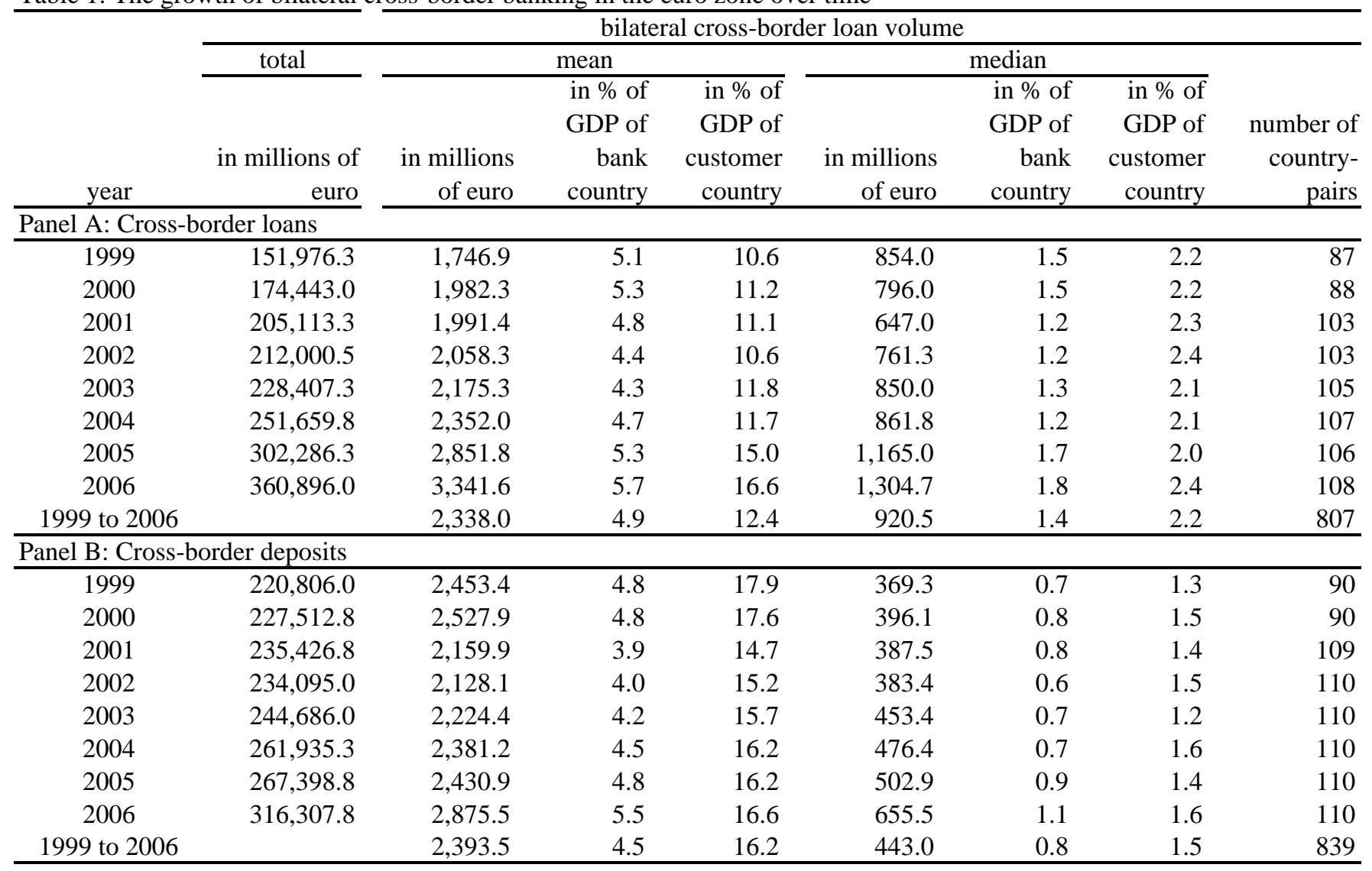

Note: Descriptive statistics are based on full information sample of countrypair- and year-specific observations used in the regressions. Means and medians are calculated across all country-pairs which have non-zero bilateral loan or deposit volumes. 


\begin{tabular}{|c|c|c|c|c|c|c|c|c|}
\hline \multirow[b]{3}{*}{ mean across all observations in cross-border-loan-quartile for variable: } & \multicolumn{4}{|c|}{ cross-border loans } & \multicolumn{4}{|c|}{ cross-border deposits } \\
\hline & \multicolumn{2}{|c|}{1999} & \multicolumn{2}{|c|}{2006} & \multicolumn{2}{|c|}{1999} & \multicolumn{2}{|c|}{2006} \\
\hline & $\begin{array}{l}\text { bottom } \\
\text { quartile }\end{array}$ & $\begin{array}{c}\text { top } \\
\text { quartile }\end{array}$ & $\begin{array}{l}\text { bottom } \\
\text { quartile }\end{array}$ & $\begin{array}{c}\text { top } \\
\text { quartile }\end{array}$ & $\begin{array}{l}\text { bottom } \\
\text { quartile }\end{array}$ & $\begin{array}{c}\text { top } \\
\text { quartile }\end{array}$ & $\begin{array}{l}\text { bottom } \\
\text { quartile }\end{array}$ & $\begin{array}{c}\text { top } \\
\text { quartile }\end{array}$ \\
\hline \multicolumn{9}{|l|}{ cross-border loans and deposits } \\
\hline loans or deposits as bilateral, annual cross-border loan volume (in millions of euro) & 52.60 & 4,971.92 & 31.06 & $10,443.36$ & 26.41 & $8,526.18$ & 21.62 & $9,508.08$ \\
\hline \multicolumn{9}{|l|}{ economic mass } \\
\hline GDP of bank country (in billions of euro) & 386.36 & $1,022.35$ & 342.27 & $1,407.47$ & 271.18 & $1,009.07$ & 402.45 & $1,155.50$ \\
\hline GDP of customer country (in billions of euro) & 438.65 & 855.45 & 551.86 & 912.91 & 372.67 & 972.88 & 495.89 & $1,028.83$ \\
\hline total GDP of bank and customer country (in billions of euro) & 825.01 & $1,877.80$ & 894.14 & $2,320.37$ & 6.18 & 7.46 & 6.58 & 7.55 \\
\hline \multicolumn{9}{|l|}{ financial development } \\
\hline credit to the private sector in \% of GDP in bank country & 0.80 & 1.00 & 0.98 & 1.21 & 0.77 & 1.01 & 1.02 & 1.26 \\
\hline credit to the private sector in \% of GDP in customer country & 0.91 & 0.97 & 1.14 & 1.34 & 0.87 & 1.00 & 1.16 & 1.37 \\
\hline difference between credit to the private sector in bank versus customer country & 1.48 & 1.30 & 1.46 & 1.45 & 0.43 & 0.23 & 0.40 & 0.33 \\
\hline similarity of credit to the private sector in bank versus customer country & 0.30 & 0.27 & 0.33 & 0.33 & -1.35 & -1.48 & -1.24 & -1.25 \\
\hline market share of foreign banks in bank country & 11.26 & 17.67 & 31.84 & 13.25 & 15.53 & 13.81 & 32.03 & 15.33 \\
\hline market share of foreign banks in customer country & 20.78 & 19.17 & 32.05 & 24.88 & 21.25 & 18.07 & 29.35 & 24.23 \\
\hline market share of foreign banks $\mathrm{ED}_{\mathrm{E}}$ & 19.40 & 23.91 & 26.30 & 20.99 & 22.53 & 19.70 & 26.10 & 22.52 \\
\hline deposit insurance coverage in euro for bank country & & & & & 27,969.19 & $28,478.26$ & $30,709.79$ & $37,199.38$ \\
\hline deposit insurance coverage in euro for customer country & & & & & $26,664.84$ & $31,230.06$ & $30,949.38$ & $30,117.55$ \\
\hline deposit insurance per depositor ${ }_{D}$ for bank country & & & & & 0.74 & 0.78 & 0.86 & 0.82 \\
\hline deposit insurance per depositor ${ }_{D}$ for customer country & & & & & 0.87 & 0.87 & 0.82 & 0.89 \\
\hline deposit insurance preference & & & & & 0.57 & 0.54 & 0.48 & 0.54 \\
\hline \multicolumn{9}{|l|}{ geographic, cultural and political features } \\
\hline common legal family ${ }_{D}$ & 0.27 & 0.36 & 0.33 & 0.48 & 0.09 & 0.48 & 0.32 & 0.50 \\
\hline common border $_{D}$ & 0.05 & 0.50 & 0.00 & 0.56 & 0.00 & 0.70 & 0.04 & 0.57 \\
\hline common language $_{\mathrm{D}}$ & 0.05 & 0.23 & 0.00 & 0.26 & 0.00 & 0.30 & 0.00 & 0.29 \\
\hline distance in km between capital cities & $1,691.39$ & 920.44 & $2,005.67$ & 881.16 & $1,836.17$ & 806.92 & $2,031.41$ & 779.98 \\
\hline culture $_{\mathrm{ED}}$ & 2.67 & 2.32 & 2.98 & 2.28 & 2.55 & 2.14 & 2.89 & 2.22 \\
\hline trust $_{\mathrm{ED}}$ & 1.11 & 0.63 & 1.11 & 0.77 & 1.21 & 0.75 & 1.12 & 0.81 \\
\hline World Bank's worldwide governance indicators: & & & & & & & & \\
\hline overall political risk $\mathrm{ED}_{\mathrm{E}}$ & 0.01 & -0.11 & 0.55 & -0.01 & 1.04 & 0.86 & 1.87 & 1.00 \\
\hline control of corruption $\mathrm{ED}_{\mathrm{E}}$ & 1.21 & 1.04 & 1.21 & 0.61 & 1.04 & 0.86 & 1.15 & 0.48 \\
\hline government effectiveness $_{\mathrm{ED}}$ & 0.46 & 0.37 & 0.86 & 0.49 & 0.33 & 0.26 & 0.83 & 0.39 \\
\hline polical stability and absence of violence ${ }_{\mathrm{ED}}$ & 1.21 & 1.04 & 1.95 & 1.18 & 0.33 & 0.33 & 0.57 & 0.38 \\
\hline regulatory quality $\mathrm{ED}_{\mathrm{E}}$ & 0.48 & 0.51 & 0.55 & 0.40 & 0.44 & 0.43 & 0.52 & 0.36 \\
\hline voice and accountability $\mathrm{ED}$ & 0.21 & 0.19 & 0.35 & 0.23 & 0.17 & 0.16 & 0.32 & 0.21 \\
\hline rule of law $\mathrm{ED}_{\mathrm{ED}}$ & 0.48 & 0.35 & 0.81 & 0.49 & 0.40 & 0.26 & 0.77 & 0.37 \\
\hline number of counrypair-specific observations in quartile & 22 & 22 & 27 & 27 & 23 & 23 & 28 & 28 \\
\hline
\end{tabular}

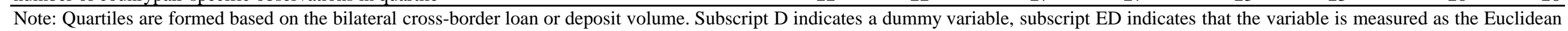
distance between the customer and bank country. Higher Euclidean distances indicate higher differences between countries. 


\begin{tabular}{|c|c|c|c|c|c|}
\hline \multicolumn{2}{|c|}{ Fixed effects } & \multicolumn{2}{|c|}{ Dynamic } & \multicolumn{2}{|c|}{ LSDV } \\
\hline $\begin{array}{l}\text { GDP proxies } \\
\text { for SIMILAR } \\
\text { and REL }\end{array}$ & $\begin{array}{c}\text { credit market } \\
\text { proxies for } \\
\text { SIMILAR and REL }\end{array}$ & $\begin{array}{l}\text { GDP proxies } \\
\text { for SIMILAR } \\
\text { and REL }\end{array}$ & $\begin{array}{c}\text { credit market } \\
\text { proxies for } \\
\text { SIMILAR and REL }\end{array}$ & $\begin{array}{l}\text { GDP proxies for SIMILAR and } \\
\text { REL }\end{array}$ & $\begin{array}{l}\text { credit market proxies for } \\
\text { SIMILAR and REL }\end{array}$ \\
\hline baseline & baseline & baseline & baseline & baseline $\quad$ preferred & baseline $\quad$ preferred \\
\hline
\end{tabular}

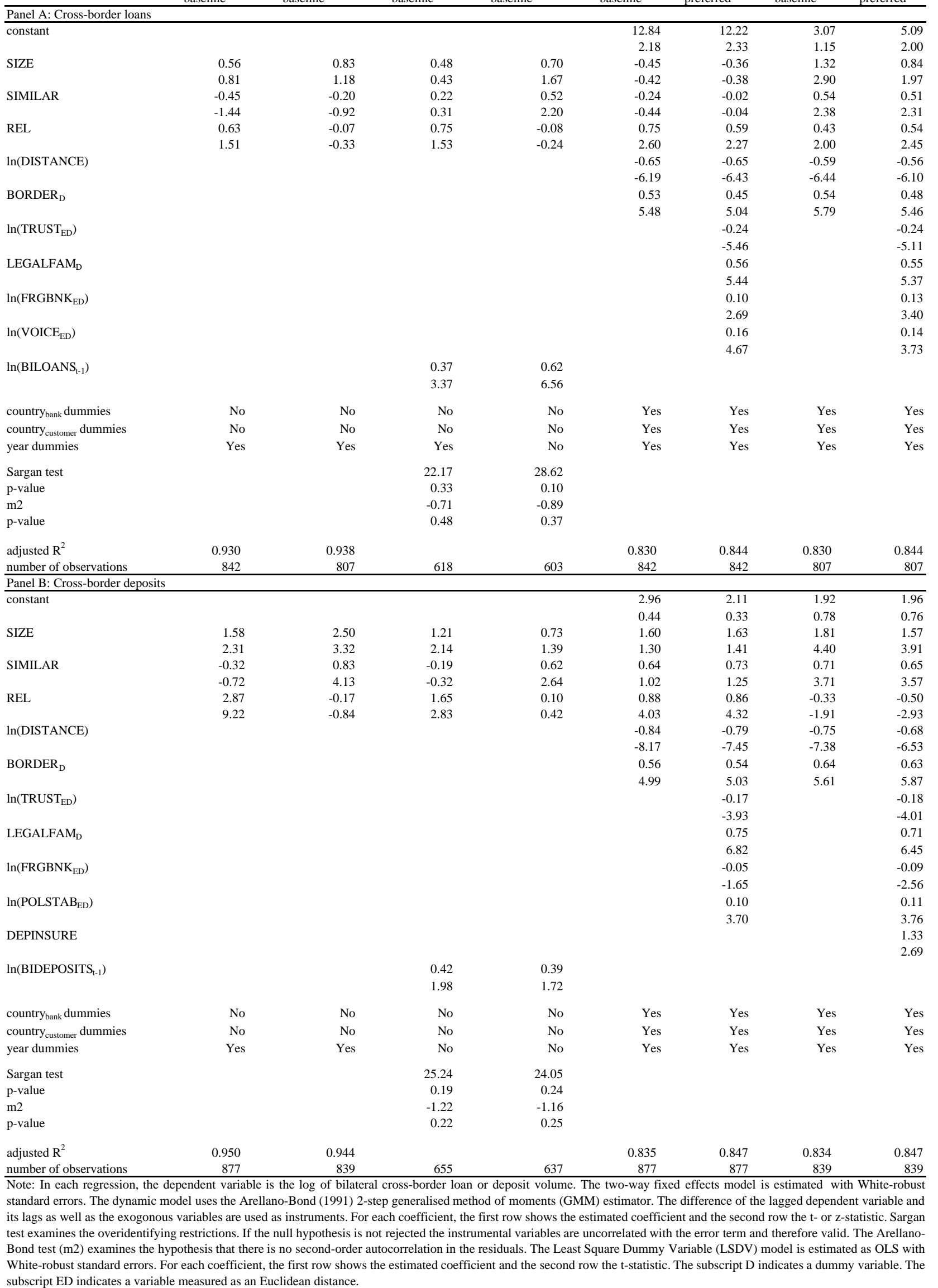

baseline SIMILAR and REL $\quad$ and REL SIMILAR and R baseline preferred baseline preferred 


\begin{tabular}{|c|c|c|c|c|c|c|c|c|c|c|c|c|}
\hline & \multicolumn{6}{|c|}{ Loans } & \multicolumn{6}{|c|}{ Deposits } \\
\hline & \multicolumn{2}{|c|}{$\begin{array}{l}\text { Credit market proxies for } \\
\text { SIMILAR and REL } \\
\end{array}$} & \multicolumn{4}{|c|}{$\begin{array}{c}\text { GDP proxies for SIMILAR } \\
\text { and REL }\end{array}$} & \multicolumn{2}{|c|}{$\begin{array}{l}\text { Credit market proxies for } \\
\text { SIMILAR and REL }\end{array}$} & \multicolumn{4}{|c|}{$\begin{array}{c}\text { GDP proxies for SIMILAR } \\
\text { and REL }\end{array}$} \\
\hline & $\begin{array}{c}\text { without } \\
\text { TRADEVOL }\end{array}$ & $\begin{array}{c}\text { including } \\
\text { TRADEVOL }\end{array}$ & $\begin{array}{r}\text { witho } \\
\text { TRADE }\end{array}$ & $\begin{array}{l}\text { ut } \\
\text { VOL }\end{array}$ & $\begin{array}{r}\text { includ } \\
\text { TRADE }\end{array}$ & $\begin{array}{l}\text { ing } \\
\text { VOL }\end{array}$ & $\begin{array}{c}\text { without } \\
\text { TRADEVOL }\end{array}$ & $\begin{array}{c}\text { including } \\
\text { TRADEVOL }\end{array}$ & $\begin{array}{r}\text { witho } \\
\text { TRADE }\end{array}$ & $\begin{array}{l}\text { ut } \\
\text { VOL }\end{array}$ & $\begin{array}{r}\text { includi } \\
\text { TRADE }\end{array}$ & $\begin{array}{l}\text { ing } \\
\mathrm{VOL}\end{array}$ \\
\hline $\ln ($ FRGBNK bank country $)$ & -0.05 & -0.06 & -0.09 & & -0.10 & & -0.06 & -0.05 & -0.03 & & -0.03 & \\
\hline $\ln ($ FRGBNK customer country $)$ & $-0.14 *$ & -0.12 & -0.15 & * & -0.15 & $*$ & -0.06 & -0.06 & -0.04 & & -0.03 & \\
\hline $\ln \left(\mathrm{FRGBNK} \mathrm{ED}_{\mathrm{ED}}\right)$ & $0.11 *$ & 0.12 & 0.08 & $*$ & 0.10 & $*$ & $-0.10 *$ & $-0.09 *$ & -0.07 & * & -0.06 & \\
\hline LANGUAGE $_{\mathrm{D}}$ & 0.11 & 0.00 & 0.02 & & -0.07 & & 0.24 & 0.18 & 0.07 & & 0.03 & \\
\hline $\ln \left(C_{U L T U R E}\right)$ & $-0.34 *$ & $-0.28 *$ & -0.35 & $*$ & -0.33 & $*$ & -0.07 & -0.05 & -0.19 & & -0.18 & \\
\hline ln(TRUST\&CULTURE 3 ) & $-0.33 *$ & $-0.19 *$ & -0.32 & $*$ & -0.25 & $*$ & -0.05 & 0.01 & -0.09 & & -0.05 & \\
\hline ln(TRUST\&CULTURE 4 ) & $-0.39 *$ & $-0.29 *$ & -0.38 & * & -0.33 & $*$ & -0.15 & -0.09 & -0.23 & $*$ & -0.20 & * \\
\hline $\ln \left(\mathrm{TRUST}_{\mathrm{ED}}\right)$ & $-0.24 *$ & $-0.18 *$ & -0.23 & $*$ & -0.20 & $*$ & $-0.22 *$ & $-0.19 *$ & -0.22 & $*$ & -0.19 & $*$ \\
\hline LEGALFAM $_{D}$ & $0.66 *$ & $0.54 *$ & 0.67 & * & 0.59 & $*$ & $0.74 *$ & $0.65 *$ & 0.78 & $*$ & 0.72 & $*$ \\
\hline $\ln \left(\mathrm{POL}_{\mathrm{ED}}\right)$ & $-0.01 *$ & 0.09 & 0.06 & & 0.14 & & 0.03 & 0.12 & -0.02 & & 0.06 & \\
\hline $\ln \left(\mathrm{CORRUP} \mathrm{ED}_{\mathrm{ED}}\right)$ & -0.01 & 0.04 & 0.00 & & 0.04 & & -0.01 & 0.04 & -0.02 & & 0.02 & \\
\hline $\ln \left(\mathrm{GOVEFF}_{\mathrm{ED}}\right)$ & 0.03 & 0.06 & 0.05 & & 0.07 & $*$ & 0.01 & 0.03 & 0.00 & & 0.02 & \\
\hline $\ln \left(\mathrm{POLSTAB}_{\mathrm{ED}}\right)$ & -0.03 & -0.01 & 0.00 & & 0.01 & & $0.06 *$ & $0.09 *$ & 0.05 & & 0.08 & $*$ \\
\hline $\ln \left(\mathrm{REGQAL}_{\mathrm{ED}}\right)$ & -0.06 & -0.02 & -0.03 & & 0.00 & & -0.07 & -0.03 & -0.08 & $*$ & -0.05 & \\
\hline $\ln \left(\mathrm{VOICE}_{\mathrm{ED}}\right)$ & $0.09 *$ & $0.10 *$ & 0.12 & $*$ & 0.13 & & 0.03 & 0.05 & 0.03 & & 0.06 & \\
\hline $\ln \left(\mathrm{LAW}_{\mathrm{ED}}\right)$ & 0.00 & 0.05 & 0.02 & & 0.06 & & 0.03 & $0.07 *$ & -0.03 & & 0.01 & \\
\hline $\ln \left(\right.$ COVERAGE $\left.E_{\text {bank country }}\right)$ & & & & & & & 0.28 & 0.31 & -0.44 & & -0.35 & \\
\hline $\ln \left(\right.$ COVERAGE $\left.E_{\text {customer country }}\right)$ & & & & & & & -0.61 & -0.94 & -0.56 & & -0.90 & \\
\hline $\ln \left(\mathrm{COVERAGE} \mathrm{ED}_{\mathrm{E}}\right)$ & & & & & & & $-0.29 *$ & $-0.26 *$ & -0.23 & $*$ & -0.21 & \\
\hline $\ln \left(\right.$ COVRATIO bank country $_{\text {) }}$ & & & & & & & -0.81 & -0.80 & -0.40 & & -0.39 & \\
\hline $\ln ($ COVRATIO customer country $)$ & & & & & & & 0.29 & 0.13 & 0.45 & & 0.31 & \\
\hline $\ln ($ COVRATIO $\mathrm{ED})$ & & & & & & & 0.01 & 0.02 & -0.01 & & 0.00 & \\
\hline DEPINS $_{\mathrm{D} \text {, bank country }}$ & & & & & & & $-0.67 *$ & $-0.70 *$ & -0.71 & & -0.70 & \\
\hline DEPINS $_{\mathrm{D} \text {, customer country }}$ & & & & & & & $1.54 *$ & $2.92 *$ & 0.93 & & 2.07 & \\
\hline DEPINSURE & & & & & & & $1.33 *$ & $1.39 *$ & 1.43 & & 1.40 & \\
\hline
\end{tabular}

Note: A Least Square Dummy Variable (LSDV) model is estimated as OLS with White-robust standard errors. The subscript D indicates a dummy variable. The subscript ED indicates a variable measured as an Euclidean distance. Each explanatory variable is included separately in the respective baseline model presented in Table 3. * indicates significance at least at $10 \%$. 


\section{BILOANS}

\section{BIDEPOSITS}

bilateral cross border loan

volume

bilateral cross-border deposit

volume

gross domestic product

, variation across

variation across it or $\mathrm{jt}$

population $_{\text {it }}$ population $_{\mathrm{jt}}$

privat credit to GDP

variation across it or $\mathrm{jt}$

money $_{\text {it }}$ to GDP

variation across it or $\mathrm{j}$

variation across it or jt

deposit $_{\text {it }}$ to GDP

combined economic masses $\quad \ln$, variation across ijt

absolute difference in per capita ln, variation across ijt GDP

REL

SIMILAR

REL_X

SIMILAR_X

DISTANCE

\section{distance}

BORDER

common border

dummy, variation across ij

FRGBNK

asset share of foreign banks

ln, euclidean distance, variation across ijt

dummy, variation across ij

ln, euclidean distance, variation across $i j$ euclidean distance, variation across ij
LANGUAGE

CULTURE

TRUST culture

trust

Outstanding bilateral, cross-border loan volume in millions of euros in year t. All loans from monetary and financial institutions (MFIs) in country $i$ to non-MFI borrowers in country $j$ are included.

Outstanding bilateral, cross-border deposit volume in millions of euros in year t. All deposits from MFIs in country i to non-MFI borrowers in country j are included.

GDP in billions of euro of country i (or j) in year t. GDP is measured at current prices and is not seasonally adjusted except for Portugal for which the GDP is seasonally adjusted. Source: Eurostat's series ESNGDPA for all countries except Greece and Luxembourg. For these two countries, the series 99B..A from the IMF's IFS are used.

Population of country i (or j) in million in mid-year t. Source: Series I99Z..O from the IMF's IFS.

Credit to private sector as percent of gdp for country i (or j) in year t. Source: IMF's IFS credit series Y32D..A and GDP as defined above.

Money of country i (or j) in year $t$ is defined as currency plus deposits in percent of GDP. Source: IMF's IFS currency series Y34A.NA, demand deposit series Y34B.NA and other deposit series Y35..NA. GDP as defined above.

Deposits as percent of GDP for country i (or j) in year t. Source: IMF's IFS demand deposit series Y3B.NA and other deposit series Y35..NA. GDP as defined above.

$=\ln \left(\mathrm{GDP}_{\mathrm{it}}+\mathrm{GDP}_{\mathrm{jt}}\right)$. Total size of the economy of country $\mathrm{i}$ and $\mathrm{j}$.

$=\left|\ln \left(\mathrm{GDP}_{\mathrm{it}} / \mathrm{POP}_{\mathrm{it}}\right)-\ln \left(\mathrm{GDP}_{\mathrm{jt}} / \mathrm{POP}_{\mathrm{jt}}\right)\right|$

$=\ln \left(1-\left(\mathrm{GDP}_{\mathrm{it}} /\left(\mathrm{GDP}_{\mathrm{it}}+\mathrm{GDP}_{\mathrm{jt}}\right)\right)^{2}-\left(\mathrm{GDP}_{\mathrm{it}} /\left(\mathrm{GDP}_{\mathrm{it}}+\mathrm{GDP}_{\mathrm{jt}}\right)^{2}\right)\right.$. The similarity of GDP in country i versus $\mathrm{j}$.

$=\left|\ln \left(\mathrm{X}_{\mathrm{it}}\right)-\ln \left(\mathrm{X}_{\mathrm{jt}}\right)\right|$. The absolute difference between financial development in country $\mathrm{i}$ versus $\mathrm{j}$. $=\ln \left(1-\left(\left(\mathrm{X}_{\mathrm{it}} * \mathrm{GDP}_{\mathrm{it}}\right) /\left(\left(\mathrm{X}_{\mathrm{it}} * \mathrm{GDP}_{\mathrm{it}}\right)+\left(\mathrm{X}_{\mathrm{jt}} * \mathrm{GDP}_{\mathrm{jt}}\right)\right)\right)^{2}-\left(\left(\mathrm{X}_{\mathrm{it}}{ }^{*} \mathrm{GDP}_{\mathrm{it}}\right) /\left(\left(\mathrm{X}_{\mathrm{it}} * \mathrm{GDP}_{\mathrm{it}}\right)+\left(\mathrm{X}_{\mathrm{jt}} * \mathrm{GDP}_{\mathrm{jt}}\right)\right)\right)^{2}\right)$. The similarity index for financial developemnt in country i versus $\mathrm{j}$.

Alternative definitions for the financial development proxy X are used: CREDIT, MONEY, DEPOSIT

Distance in km between the capital cities of countries i and j. Source: http://www.wcrl.ars.usda.gov/cec/java/latlong.htm. New link: http://www.chemical-ecology.net/java/lat-long.htm

Dummy equal to 1 if countries i and j have a common border. The following countries have a common border: Austri Germany, Austria-Italy, Belgium-France, Belgium-Germany, Belgium-Luxembourg, Belgium-Netherlands, DenmarkGermany, France-Germany, France-Italy, France-Luxembourg, France-Spain, Germany-Luxembourg, GermanyNetherlands, Portugal-Spain.

Asset share of foreign banks in banking market of country i (or j). Measured as total assets of foreign branches and subsidiaries of credit institutions (CIs) from EU and 3rd countries as percent of total assets of domestic CIs. Source for data for 1999 to 2000: ECB (2004), tables 8, 21, 23, 25 and 27 from annex 1. Source for data for 2001 to 2005: ECB (2006), tables 2, 11 and 13 from annex 1. Data for 2006 is not yet available and data for 2005 is used instead.

Dummy equal to 1 if countries $i$ and $j$ have common language. The following country-pairs are considered to have a common language: Germany-Austria, Belgium-France, Belgium-Netherlands, Austria-Luxembourg, BelgiumLuxembourg, Germany-Luxembourg, France-Luxembourg.

Four cultural dimensions of Hofstede. Estimated values are used for Luxembourg. Source: http://www.geertHofstede.com /hofstede_dimensions.php?culture1=86\&culture2=18Appea

The extend to which citizens of country i trust country j. This time-invariant proxy is based on several Eurobarometer surveys from 1970 to 1995 and scaled from 1 to 4 with higher values indicating more trust. Source: Table 1 of Guiso, Sapienza and Zingales (2004) 


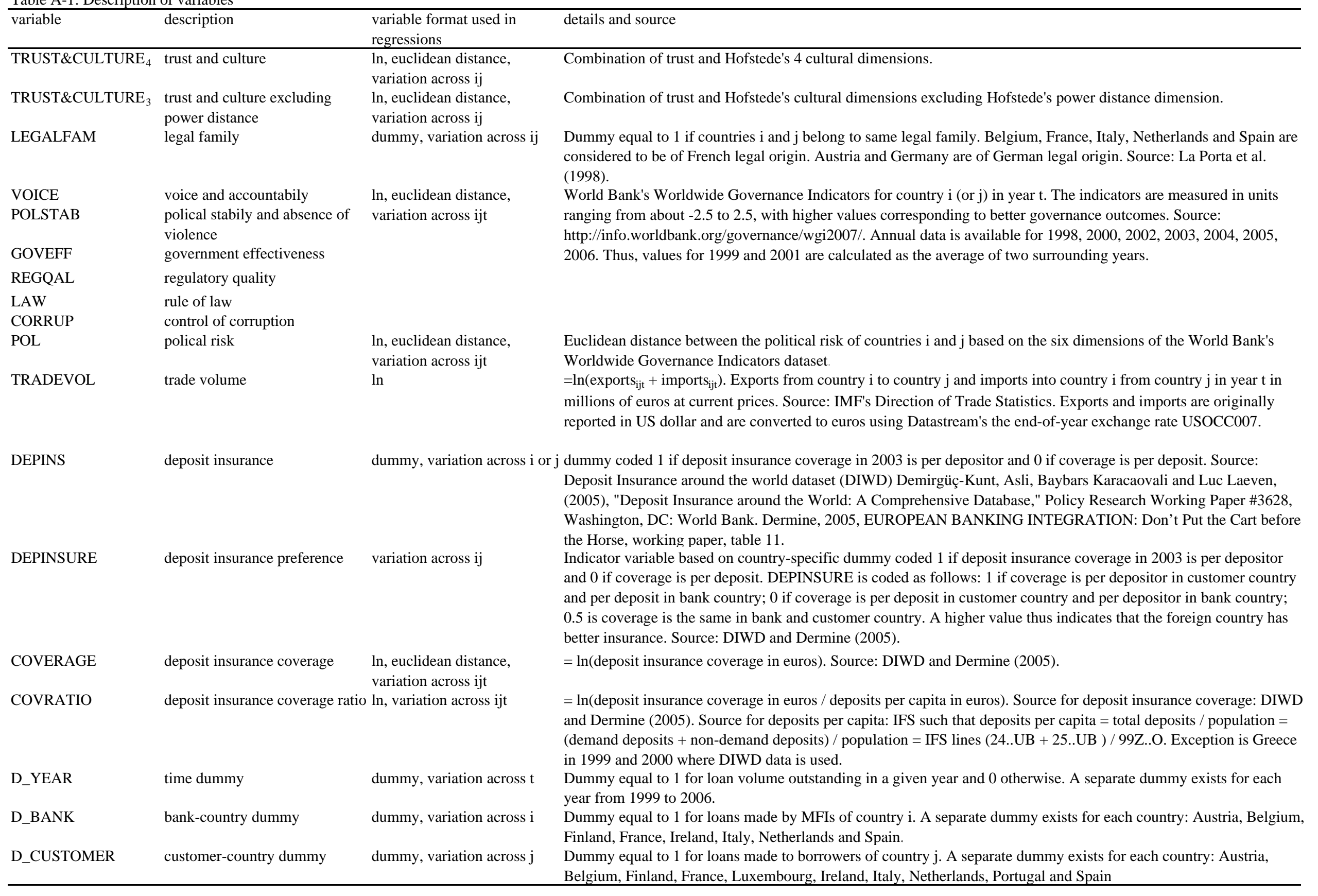


Table A2: Comparison of Estimators: Random Effects vs Fixed Effects Approach

\begin{tabular}{|c|c|c|c|c|c|c|c|c|c|c|c|c|c|c|c|c|}
\hline & \multicolumn{8}{|c|}{ Credit market proxies for SIMILAR and REL } & \multicolumn{8}{|c|}{ GDP proxies for SIMILAR and REL } \\
\hline & \multicolumn{4}{|c|}{ Model 1} & \multicolumn{4}{|c|}{$\begin{array}{ll}\text { Model } 2 \\
\end{array}$} & \multicolumn{4}{|c|}{ Model 3} & \multicolumn{4}{|c|}{ Model 4} \\
\hline & $\begin{array}{l}\text { One-way } \\
\text { random } \\
\text { effect }\end{array}$ & $\begin{array}{c}\text { One-way fixed } \\
\text { effects }\end{array}$ & $\begin{array}{c}\text { One-way } \\
\text { random } \\
\text { effects with } \\
\text { time } \\
\text { dummies } \\
\end{array}$ & $\begin{array}{c}\text { Two-way fixed } \\
\text { effects }\end{array}$ & $\begin{array}{c}\text { One-way } \\
\text { random } \\
\text { effect }\end{array}$ & $\begin{array}{c}\text { One-way fixed } \\
\text { effects }\end{array}$ & $\begin{array}{l}\text { One-way } \\
\text { random } \\
\text { effects with } \\
\text { time } \\
\text { dummies } \\
\end{array}$ & $\begin{array}{c}\text { Two-way fixed } \\
\text { effects }\end{array}$ & $\begin{array}{c}\text { One-way } \\
\text { random } \\
\text { effect }\end{array}$ & $\begin{array}{c}\text { One-way fixed } \\
\text { effects }\end{array}$ & $\begin{array}{l}\text { One-way } \\
\text { random } \\
\text { effects with } \\
\text { time } \\
\text { dummies } \\
\end{array}$ & $\begin{array}{c}\text { Two-way fixed } \\
\text { effects }\end{array}$ & $\begin{array}{c}\text { One-way } \\
\text { random } \\
\text { effect }\end{array}$ & $\begin{array}{c}\text { One-way fixed } \\
\text { effects }\end{array}$ & $\begin{array}{l}\text { One-way } \\
\text { random } \\
\text { effects with } \\
\text { time } \\
\text { dummies } \\
\end{array}$ & $\begin{array}{c}\text { Two-way fixed } \\
\text { effects }\end{array}$ \\
\hline \multicolumn{17}{|l|}{ Panel A: Cross-border loans } \\
\hline \multirow[t]{2}{*}{ SIZE } & $2.10 *$ & $2.42 *$ & $1.56^{*}$ & 0.83 & $1.57 *$ & $2.15 *$ & $0.70^{* *}$ & 0.67 & $1.83 *$ & $1.90 *$ & $1.39 *$ & -0.13 & $1.06 *$ & $1.50 *$ & 0.42 & -0.49 \\
\hline & 12.78 & 9.57 & 6.43 & 1.18 & 6.87 & 7.05 & 2.16 & 0.93 & 11.40 & 7.40 & 4.92 & -0.18 & 4.82 & 4.95 & 1.22 & -0.67 \\
\hline \multirow[t]{2}{*}{ SIMILAR } & 0.27 & 0.18 & 0.02 & -0.20 & 0.20 & 0.16 & -0.14 & -0.20 & 0.13 & 0.22 & -0.17 & $-0.90 * * *$ & -0.09 & 0.20 & -0.51 & $-0.93 * * *$ \\
\hline & 1.64 & 1.23 & 0.09 & -0.92 & 1.21 & 1.12 & -0.74 & -0.92 & 0.48 & 0.52 & -0.51 & -1.67 & -0.35 & 0.48 & -1.58 & -1.73 \\
\hline \multirow[t]{2}{*}{ REL } & -0.01 & -0.06 & -0.13 & -0.07 & 0.00 & -0.06 & -0.12 & -0.06 & 0.64 & $0.87 * *$ & $0.61 * * *$ & $0.98 * *$ & $0.89 *$ & $0.90 * *$ & $0.77 * *$ & $1.01 * *$ \\
\hline & -0.03 & -0.28 & -0.63 & -0.33 & 0.01 & -0.31 & -0.57 & -0.30 & $1.96 * *$ & 2.17 & 1.81 & 2.46 & 2.72 & 2.27 & 2.30 & 2.54 \\
\hline In(TRADEVOL) & & & & & $\begin{array}{l}0.37 * \\
3.27\end{array}$ & $\begin{array}{l}0.23 \\
1.54\end{array}$ & $\begin{array}{l}0.48 * \\
3.89\end{array}$ & $\begin{array}{l}0.14 \\
0.90\end{array}$ & & & & & $\begin{array}{l}0.53 * \\
4.98\end{array}$ & $\begin{array}{l}0.32 * \\
2.67\end{array}$ & $\begin{array}{l}0.54 * \\
4.57\end{array}$ & $\begin{array}{l}0.27 \text { ** } \\
2.21\end{array}$ \\
\hline Hausman test statstics (HT) & 6.65 & & 48.60 & & 29.35 & & 51.72 & & 4.46 & & 35.25 & & 28.43 & & 41.42 & \\
\hline HT (p-value) & 0.08 & & 0.00 & & 0.00 & & 0.00 & & 0.22 & & 0.00 & & 0.00 & & 0.00 & \\
\hline Likelihood ratio test (LR) & & 2144.42 & & 2158.34 & & 1953.21 & & 1964.86 & & 2136.64 & & 2159.16 & & 1898.83 & & 1909.17 \\
\hline LR (p-value) & & 0.00 & & 0.00 & & 0.00 & & 0.00 & & 0.00 & & 0.00 & & 0.00 & & 0.00 \\
\hline number of observations & & 807 & 807 & 807 & & 807 & 807 & 807 & 842 & 842 & 842 & 842 & 842 & 842 & 842 & 842 \\
\hline \multicolumn{17}{|l|}{ Panel B: Cross-border deposits } \\
\hline \multirow[t]{2}{*}{ SIZE } & $2.03 *$ & $2.19 *$ & $1.82 *$ & $2.50 *$ & $1.78 *$ & $2.30 *$ & $1.34 *$ & $2.60 *$ & $2.17 *$ & $2.28 *$ & $1.96 *$ & $1.58 * *$ & $1.85 *$ & $2.37 *$ & $1.43 *$ & $1.72 * *$ \\
\hline & 13.67 & 9.67 & 7.78 & 3.32 & 8.29 & 7.97 & 4.08 & 3.38 & 15.42 & 10.94 & 7.99 & 2.31 & 9.41 & 9.31 & 4.24 & 2.48 \\
\hline \multirow{2}{*}{ SIMILAR } & $0.66 *$ & $0.75 *$ & $0.58 *$ & $0.83 *$ & $0.62 *$ & $0.77 *$ & $0.48 *$ & $0.84 *$ & 0.35 & 0.05 & 0.20 & -0.32 & 0.24 & 0.08 & -0.03 & -0.27 \\
\hline & 4.25 & 4.31 & 3.28 & 4.13 & 3.92 & 4.37 & 2.63 & 4.16 & 1.37 & 0.15 & 0.71 & -0.72 & 0.91 & 0.23 & -0.09 & -0.62 \\
\hline \multirow[t]{2}{*}{ REL } & -0.15 & -0.13 & -0.21 & -0.17 & -0.15 & -0.12 & -0.20 & -0.17 & $2.39 *$ & $2.84 *$ & $2.36 *$ & 2.87 & $2.49 *$ & $2.83 *$ & $2.48 *$ & $2.86 *$ \\
\hline & -0.80 & -0.64 & -1.09 & -0.84 & -0.79 & -0.61 & -1.07 & -0.84 & 8.56 & 9.12 & 8.39 & $9.22 *$ & 8.83 & 9.13 & 8.68 & 9.22 \\
\hline \multirow[t]{2}{*}{$\ln$ InRADEVOL) } & & & & & 0.19 & -0.10 & $0.27 * *$ & -0.12 & & & & & $0.26 * *$ & -0.08 & $0.30 * *$ & -0.18 \\
\hline & & & & & $1.69 * * *$ & -0.63 & 2.12 & 0.65 & & & & & 2.39 & -0.58 & 2.38 & -1.06 \\
\hline Hausman test statstics (HT) & 7.58 & & 20.62 & & 47.44 & & 44.93 & & 16.13 & & 21.56 & & 54.26 & & 50.91 & \\
\hline HT (p-value) & 0.06 & & 0.00 & & 0.00 & & 0.00 & & 0.00 & & 0.00 & & 0.00 & & 0.00 & \\
\hline Likelihood ratio test (LR) & & 2223.49 & & 2230.69 & & 1835.14 & & 1842.43 & & 2417.68 & & 2422.69 & & 1892.43 & & 1898.62 \\
\hline LR (p-value) & & 0.00 & & 0.00 & & 0.00 & & 0.00 & & 0.00 & & 0.00 & & 0.00 & & 0.00 \\
\hline number of observations & 839 & 839 & 839 & 839 & 839 & 839 & 839 & & 877 & 877 & 877 & 877 & 877 & 877 & 877 & 877 \\
\hline
\end{tabular}


Table A3: Baseline model selection using different definitions of size, similarity and absolute differences in factor endowments

\begin{tabular}{cccc}
\multicolumn{4}{c}{ Fixed effects } \\
\hline credit & deposit & \\
pDP & market & market & money \\
for & proxies & proxies & proxies \\
for & for & for
\end{tabular}

$\frac{\text { Dynamic }}{\text { credit market deposit market }}$

\begin{tabular}{cccc}
\multicolumn{4}{c}{ LSDV } \\
\hline GDP & credit & deposit \\
market & market & money \\
for & proxies & proxies & proxies \\
for & for & for
\end{tabular}

SIMILAR SIMILAR SIMILAR SIMILAR for SIMILAR SIMILAR and SIMILAR and for SIMILAR SIMILAR SIMILAR SIMILAR SIMILAR and REL and REL and REL and REL and REL

REL
and REL

and REL and REL and REL and REL

\begin{tabular}{|c|c|c|c|c|c|c|c|c|c|c|c|c|c|c|c|c|}
\hline \multicolumn{17}{|c|}{ Panel A: Cross-border loans } \\
\hline \multirow[t]{2}{*}{ constant } & & & & & & & & & & & & & 12.84 & 3.07 & 8.17 & 8.13 \\
\hline & & & & & & & & & & & & & 2.18 & 1.15 & 2.17 & 2.00 \\
\hline \multirow[t]{2}{*}{ SIZE } & 0.56 & 0.83 & 0.56 & 0.44 & 0.48 & 0.66 & 0.30 & 0.70 & 0.84 & 0.68 & 0.69 & 0.76 & -0.45 & 1.32 & -0.07 & -0.04 \\
\hline & 0.81 & 1.18 & 0.81 & 0.64 & 0.43 & 1.74 & 0.29 & 1.67 & 0.86 & 1.88 & 0.69 & 2.14 & -0.42 & 2.90 & -0.12 & -0.06 \\
\hline \multirow[t]{2}{*}{ SIMILAR } & -0.45 & -0.20 & -0.45 & -0.50 & 0.22 & 1.29 & 0.06 & 0.52 & 0.60 & 1.07 & 0.60 & 1.02 & -0.24 & 0.54 & -0.24 & -0.21 \\
\hline & -1.44 & -0.92 & -1.44 & -1.49 & 0.31 & 1.77 & 0.18 & 2.20 & 1.18 & 3.22 & 1.19 & 2.96 & -0.44 & 2.38 & -0.73 & -0.60 \\
\hline \multirow[t]{2}{*}{ REL } & 0.63 & -0.07 & 0.63 & 1.02 & 0.75 & 1.14 & -0.10 & -0.08 & -0.21 & 0.40 & -0.01 & 0.38 & 0.75 & 0.43 & 1.31 & 1.29 \\
\hline & 1.51 & -0.33 & 1.51 & 1.98 & 1.53 & 2.02 & -0.35 & -0.24 & -0.07 & 1.40 & -0.04 & 1.15 & 2.60 & 2.00 & 4.48 & 4.09 \\
\hline \multirow[t]{2}{*}{ ln(DISTANCE) } & & & & & & & & & & & & & -0.65 & -0.59 & -0.48 & -0.48 \\
\hline & & & & & & & & & & & & & -6.19 & -6.44 & -4.96 & -4.90 \\
\hline \multirow[t]{2}{*}{ BORDER $_{\mathrm{D}}$} & & & & & & & & & & & & & 0.53 & 0.54 & 0.71 & 0.70 \\
\hline & & & & & & & & & & & & & 5.48 & 5.79 & 7.27 & 7.10 \\
\hline \multirow[t]{2}{*}{$\ln \left(\right.$ BILOANS $\left._{\mathrm{t}-1}\right)$} & & & & & 0.37 & 0.57 & 0.40 & 0.62 & 0.43 & 0.62 & 0.42 & 0.60 & & & & \\
\hline & & & & & 3.37 & 6.19 & 3.69 & 6.56 & 4.03 & 7.32 & 4.03 & 7.17 & & & & \\
\hline country $_{\text {bank }}$ dummies & No & No & No & No & No & No & No & No & No & No & No & No & Yes & Yes & Yes & Yes \\
\hline country $_{\text {customer }}$ dummies & No & No & No & No & No & No & No & No & No & No & No & No & Yes & Yes & Yes & Yes \\
\hline year dummies & Yes & Yes & Yes & Yes & Yes & No & Yes & No & Yes & No & Yes & No & Yes & Yes & Yes & Yes \\
\hline Sargan test & & & & & 22.17 & 33.06 & 19.86 & 28.62 & 22.45 & 25.78 & 21.94 & 25.58 & & & & \\
\hline p-value & & & & & 0.33 & 0.03 & 0.47 & 0.10 & 0.32 & 0.17 & 0.34 & 0.18 & & & & \\
\hline $\mathrm{m} 2$ & & & & & -0.71 & -0.72 & -0.83 & -0.89 & -0.80 & -0.89 & -0.80 & -0.89 & & & & \\
\hline p-value & & & & & 0.48 & 0.47 & 0.41 & 0.37 & 0.42 & 0.37 & 0.42 & 0.38 & & & & \\
\hline adjusted $\mathrm{R}^{2}$ & 0.930 & 0.938 & 0.938 & 0.938 & & & & & & & & & 0.830 & 0.830 & 0.834 & 0.833 \\
\hline number of observations & 842 & 807 & 807 & 807 & 618 & 618 & 603 & 603 & 603 & 603 & 603 & 603 & 842 & 807 & 807 & 807 \\
\hline
\end{tabular}


Table A3: Baseline model selection using different definitions of size, similarity and absolute differences in factor endowments

\begin{tabular}{cccc}
\multicolumn{4}{c}{ Fixed effects } \\
\hline GDP & credit & deposit & \\
proxies & proxies & market & money \\
for & for & for & for
\end{tabular}

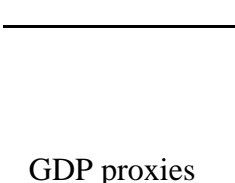
Dynamic

SIMILAR SIMILAR SIMILAR SIMILAR and REL and REL and REL and REL

credit market deposit market

SIMILAR and SIMILAR and for SIMILAR and REL

REL

REL
and REL

\begin{tabular}{cccc}
\multicolumn{4}{c}{ LSDV } \\
\hline GDP & credit & deposit \\
proxies & proxies & market & money \\
for & for & for & for \\
prosies & proxies
\end{tabular}

Panel B: Cross-border deposits

\begin{tabular}{|c|c|c|c|c|c|c|c|c|c|c|c|c|}
\hline constant & & & & & & & & & & & & \\
\hline \multirow[t]{2}{*}{ SIZE } & 1.58 & 2.50 & 2.01 & 2.13 & 1.20 & 1.21 & 0.51 & 0.73 & 0.36 & 0.84 & 0.16 & 0.82 \\
\hline & 2.31 & 3.32 & 2.53 & 2.72 & 0.95 & 2.14 & 0.33 & 1.39 & 0.23 & 1.39 & 0.11 & 1.41 \\
\hline \multirow[t]{2}{*}{ SIMILAR } & -0.32 & 0.83 & 1.03 & 1.28 & -0.01 & -0.19 & 0.42 & 0.62 & 0.60 & 0.72 & 0.64 & 0.69 \\
\hline & -0.72 & 4.13 & 3.28 & 3.91 & -0.02 & -0.32 & 1.36 & 2.64 & 1.26 & 2.17 & 1.35 & 2.00 \\
\hline \multirow[t]{2}{*}{ REL } & 2.87 & -0.17 & 0.25 & 0.31 & 1.20 & 1.65 & 0.00 & 0.10 & -0.12 & 0.30 & 0.06 & 0.46 \\
\hline & 9.22 & -0.84 & 0.76 & 0.83 & 2.04 & 2.83 & 0.01 & 0.42 & -0.32 & 0.82 & 0.14 & 1.22 \\
\hline \multicolumn{13}{|l|}{$\ln$ (DISTANCE) } \\
\hline \multicolumn{13}{|l|}{ BORDER $_{\mathrm{D}}$} \\
\hline \multirow{2}{*}{$\ln \left(\right.$ BIDEPOSITS $\left._{\mathrm{t}-1}\right)$} & & & & & 0.45 & 0.42 & 0.32 & 0.39 & 0.32 & 0.37 & 0.33 & 0.37 \\
\hline & & & & & 2.41 & 1.98 & 1.55 & 1.72 & 1.60 & 1.58 & 1.61 & 1.57 \\
\hline country $_{\text {bank }}$ dummies & No & No & No & No & No & No & No & No & No & No & No & No \\
\hline country $_{\text {customer }}$ dummies & No & No & No & No & No & No & No & No & No & No & No & No \\
\hline year dummies & Yes & Yes & Yes & Yes & Yes & No & Yes & No & Yes & No & Yes & No \\
\hline Sargan test & & & & & 30.35 & 25.24 & 27.20 & 24.05 & 27.61 & 24.52 & 28.42 & 24.24 \\
\hline p-value & & & & & 0.06 & 0.19 & 0.13 & 0.24 & 0.12 & 0.22 & 0.10 & 0.23 \\
\hline $\mathrm{m} 2$ & & & & & -1.22 & -1.22 & -1.14 & -1.16 & -1.13 & -1.14 & -1.14 & -1.15 \\
\hline $\mathrm{p}$-value & & & & & 0.22 & 0.22 & 0.26 & 0.25 & 0.26 & 0.26 & 0.26 & 0.25 \\
\hline
\end{tabular}

\begin{tabular}{|c|c|c|c|c|c|c|c|c|c|c|c|c|c|c|c|c|}
\hline $\begin{array}{l}\text { adjusted } \mathrm{R}^{2} \\
\text { number of observations }\end{array}$ & $\begin{array}{r}0.950 \\
877\end{array}$ & $\begin{array}{r}0.944 \\
839\end{array}$ & $\begin{array}{r}0.944 \\
839\end{array}$ & $\begin{array}{r}0.944 \\
839\end{array}$ & 655 & 655 & 637 & 637 & 637 & 637 & 637 & & $\begin{array}{r}0.835 \\
877\end{array}$ & $\begin{array}{r}0.834 \\
839\end{array}$ & $\begin{array}{r}0.833 \\
839\end{array}$ & $\begin{array}{r}0.832 \\
839\end{array}$ \\
\hline & & & & & כ5ט & 055 & 037 & 03/ & & & 03 & 631 & $8 / 7$ & 839 & 839 & 839 \\
\hline
\end{tabular}

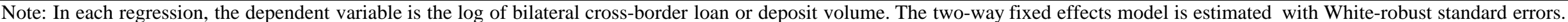

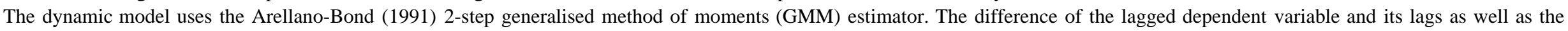

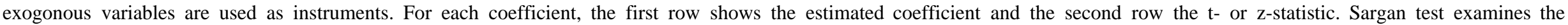

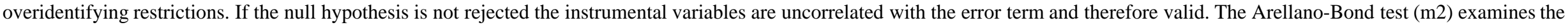

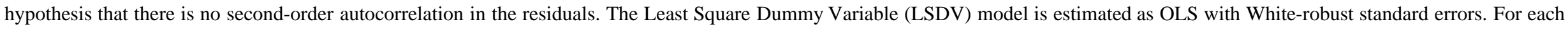
coefficient, the first row shows the estimated coefficient and the second row the t-statistic. The subscript D indicates a dummy variable. 
Table A4: LSDV model selection

Panel A1: Cross-border loans

\begin{tabular}{|c|c|c|c|c|c|c|c|c|c|c|c|c|c|c|c|c|c|c|c|c|c|c|c|}
\hline & $\operatorname{Reg} 1$ & $\operatorname{Reg} 2$ & Reg 3 & Reg 4 & Reg 5 & Reg 6 & $\operatorname{Reg} 7$ & Reg 8 & Reg 9 & $\operatorname{Reg} 10$ & $\operatorname{Reg} 11$ & Reg 12 & $\operatorname{Reg} 13$ & Reg 14 & Reg 15 & Reg 16 & Reg 17 & $\operatorname{Reg} 18$ & Reg 19 & Reg 20 & $\operatorname{Reg} 21$ & Reg 22 & $\operatorname{Reg} 23$ \\
\hline \multirow[t]{2}{*}{ constant } & 3.07 & 3.27 & $\begin{array}{ll}3.82 \\
\end{array}$ & 3.46 & 2.88 & 1.71 & 2.00 & 1.56 & 3.47 & 2.38 & 3.00 & 2.99 & 3.27 & 2.63 & 1.95 & 4.27 & 3.08 & 1.93 & 2.81 & 3.25 & 4.99 & 3.97 & 5.09 \\
\hline & 1.15 & 1.22 & 1.42 & 1.32 & 1.07 & 0.61 & 0.73 & 0.56 & 1.32 & 0.90 & 1.09 & 1.11 & 1.20 & 0.95 & 0.71 & 1.60 & 1.15 & 0.70 & 1.07 & 1.28 & 1.90 & 1.51 & 2.00 \\
\hline \multirow[t]{2}{*}{ SIZE } & 1.32 & 1.31 & 1.31 & 1.18 & 1.32 & 1.57 & 1.56 & 1.65 & 1.34 & 1.20 & 1.32 & 1.32 & 1.31 & 1.39 & 1.49 & 1.15 & 1.32 & 1.31 & 1.24 & 1.09 & 0.86 & 0.97 & 0.84 \\
\hline & 2.90 & 2.89 & 2.90 & 2.66 & 2.90 & 3.33 & 3.32 & 3.49 & 3.00 & 2.71 & 2.87 & 2.90 & 2.87 & 2.95 & 3.17 & 2.52 & 2.91 & 2.79 & 2.82 & 2.54 & 1.93 & 2.19 & 1.97 \\
\hline \multirow[t]{2}{*}{ SIMILAR_CRE } & 0.54 & 0.54 & 0.54 & 0.56 & 0.55 & 0.67 & 0.67 & 0.71 & 0.62 & 0.52 & 0.54 & 0.54 & 0.54 & 0.57 & 0.61 & 0.46 & 0.54 & 0.57 & 0.59 & 0.61 & 0.52 & 0.57 & 0.51 \\
\hline & 2.38 & 2.38 & 2.39 & 2.46 & 2.42 & 2.80 & 2.83 & 2.99 & 2.76 & 2.32 & 2.36 & 2.38 & 2.37 & 2.43 & 2.60 & 2.05 & 2.38 & 2.41 & 2.64 & 2.74 & 2.28 & 2.52 & 2.31 \\
\hline \multirow[t]{2}{*}{ REL_CRE } & 0.43 & 0.42 & 0.40 & 0.54 & 0.43 & 0.44 & 0.41 & 0.43 & 0.39 & 0.43 & 0.43 & 0.43 & 0.44 & 0.44 & 0.43 & 0.45 & 0.43 & 0.43 & 0.40 & 0.52 & 0.54 & 0.51 & 0.54 \\
\hline & 2.00 & 1.94 & 1.87 & 2.40 & 2.01 & 2.04 & 1.89 & 1.99 & 1.85 & 2.00 & 2.00 & 2.01 & 2.05 & 2.02 & 2.01 & 2.08 & 1.98 & 2.02 & 1.88 & 2.35 & 2.45 & 2.33 & 2.45 \\
\hline \multirow[t]{2}{*}{$\ln$ n(DISTANCE) } & -0.59 & -0.60 & -0.60 & -0.58 & -0.56 & -0.58 & -0.61 & -0.60 & -0.66 & -0.47 & -0.59 & -0.58 & -0.61 & -0.59 & -0.58 & -0.60 & -0.60 & -0.47 & -0.55 & -0.54 & -0.56 & -0.54 & -0.56 \\
\hline & -6.44 & -6.47 & -6.52 & -6.27 & -5.44 & -6.30 & -6.58 & -6.55 & -7.27 & -4.90 & -6.42 & -6.45 & -6.65 & -6.41 & -6.32 & -6.74 & -6.42 & -4.97 & -5.74 & -5.60 & -6.12 & -5.73 & -6.10 \\
\hline \multirow[t]{2}{*}{ BORDER $_{\mathrm{D}}$} & 0.54 & 0.54 & 0.54 & 0.53 & 0.52 & 0.49 & 0.48 & 0.48 & 0.48 & 0.52 & 0.54 & 0.54 & 0.53 & 0.53 & 0.53 & 0.56 & 0.54 & 0.50 & 0.48 & 0.46 & 0.48 & 0.47 & 0.48 \\
\hline & 5.79 & 5.77 & 5.74 & 5.63 & 5.53 & 5.22 & 5.06 & 5.13 & 5.24 & 5.95 & 5.82 & 5.75 & 5.68 & 5.61 & 5.62 & 5.95 & 5.75 & 5.71 & 5.48 & 5.27 & 5.46 & 5.27 & 5.46 \\
\hline $\ln \left(\right.$ FRGBNK $\left._{\text {bank country }}\right)$ & & $\begin{array}{l}-0.05 \\
-0.67\end{array}$ & & & & & & & & & & & & & & & & & & & & & \\
\hline \multirow[t]{2}{*}{$\ln ($ FRGBNK customer country) } & & & -0.14 & & & & & & & & & & & & & & & & & & & & \\
\hline & & & -1.80 & & & & & & & & & & & & & & & & & 0.12 & 0.13 & 0.12 & 0.13 \\
\hline \multirow[t]{2}{*}{$\ln \left(\right.$ FRGBNK $\left.{ }_{\mathrm{ED}}\right)$} & & & & 0.11 & & & & & & & & & & & & & & & & 3.34 & 3.41 & 3.29 & 3.40 \\
\hline & & & & 2.79 & & & & & & & & & & & & & & & & & & & \\
\hline \multirow[t]{2}{*}{ LANGUAGE $_{D}$} & & & & & 0.11 & & & & & & & & & & & & & & & & & & \\
\hline & & & & & 0.71 & & & & & & & & & & & & & & & & & & \\
\hline \multirow[t]{2}{*}{$\ln \left(C_{1}{ }^{2} U R E_{\mathrm{ED}}\right)$} & & & & & & -0.34 & & & & & & & & & & & & -0.13 & & & & & \\
\hline & & & & & & -3.30 & & & & & & & & & & & & -1.19 & & & & & \\
\hline \multirow[t]{2}{*}{$\ln \left(\right.$ TRUST\&CULTURE $_{3}$ ) } & & & & & & & -0.33 & & & & & & & & & & & & & & & & \\
\hline & & & & & & & -3.10 & & & & & & & & & & & & & & & & \\
\hline \multirow[t]{2}{*}{$\ln \left(\right.$ TRUST\&CULTURE $_{4}$ ) } & & & & & & & & -0.39 & & & & & & & & & & & & & & & \\
\hline & & & & & & & & -3.89 & & & & & & & & & & & & & & & \\
\hline $\ln \left(T_{R U S T}{ }_{E D}\right)$ & & & & & & & & & -0.24 & & & & & & & & & & -0.20 & -0.20 & -0.24 & -0.22 & -0.24 \\
\hline & & & & & & & & & -5.08 & & & & & & & & & & -4.32 & -4.50 & -4.75 & -4.37 & -5.11 \\
\hline LEGALFAM $_{\mathrm{D}}$ & & & & & & & & & & 0.66 & & & & & & & & 0.61 & 0.56 & 0.56 & 0.54 & 0.59 & 0.55 \\
\hline & & & & & & & & & & 6.27 & & & & & & & & 5.65 & 5.42 & 5.49 & 5.13 & 5.51 & 5.37 \\
\hline $\ln \left(\mathrm{POL}_{\mathrm{ED}}\right)$ & & & & & & & & & & & -0.01 & & & & & & & & & & & & \\
\hline & & & & & & & & & & & -0.16 & & & & & & & & & & & & \\
\hline $\ln \left(\mathrm{CORRUP}_{\mathrm{ED}}\right)$ & & & & & & & & & & & & -0.01 & & & & & & & & & & & \\
\hline & & & & & & & & & & & & -0.47 & & & & & & & & & & & \\
\hline $\ln \left(\mathrm{GOVEFF}_{\mathrm{ED}}\right)$ & & & & & & & & & & & & & 0.03 & & & & & & & & & & \\
\hline & & & & & & & & & & & & & 0.81 & & & & & & & & & & \\
\hline $\ln \left(\mathrm{POLSTAB}_{\mathrm{ED}}\right)$ & & & & & & & & & & & & & & -0.03 & & & & & & & & & \\
\hline & & & & & & & & & & & & & & -0.88 & & & & & & & & & \\
\hline $\ln \left(\mathrm{REGQAL}_{\mathrm{ED}}\right)$ & & & & & & & & & & & & & & & -0.06 & & & & & & -0.01 & 0.04 & \\
\hline & & & & & & & & & & & & & & & -1.75 & & & & & & -0.19 & 1.01 & \\
\hline $\ln \left(\right.$ VOICE $\left._{\mathrm{ED}}\right)$ & & & & & & & & & & & & & & & & 0.09 & & & & & 0.14 & & 0.14 \\
\hline & & & & & & & & & & & & & & & & 2.50 & & & & & 3.68 & & 3.73 \\
\hline $\ln \left(\mathrm{LAW}_{\mathrm{ED}}\right)$ & & & & & & & & & & & & & & & & & 0.00 & & & & & & \\
\hline & & & & & & & & & & & & & & & & & 0.07 & & & & & & \\
\hline country $_{\text {lender }}$ dummies & Yes & Yes & Yes & Yes & Yes & Yes & Yes & Yes & Yes & Yes & Yes & Yes & Yes & Yes & Yes & Yes & Yes & Yes & Yes & Yes & Yes & Yes & Yes \\
\hline country $_{\text {borrower }}$ dummies & Yes & Yes & Yes & Yes & Yes & Yes & Yes & Yes & Yes & Yes & Yes & Yes & Yes & Yes & Yes & Yes & Yes & Yes & Yes & Yes & Yes & Yes & Yes \\
\hline year dummies & Yes & Yes & Yes & Yes & Yes & Yes & Yes & Yes & Yes & Yes & Yes & Yes & Yes & Yes & Yes & Yes & Yes & Yes & Yes & Yes & Yes & Yes & Yes \\
\hline adjusted $\mathrm{R}^{2}$ & 0.830 & 0.830 & 0.830 & 0.831 & 0.830 & 0.831 & 0.831 & 0.832 & 0.835 & 0.836 & 0.830 & 0.830 & 0.830 & 0.830 & 0.830 & 0.831 & 0.830 & 0.836 & 0.839 & 0.841 & 0.844 & 0.841 & 0.844 \\
\hline number of observations & 807 & 807 & 807 & 807 & 807 & 807 & 807 & 807 & 807 & 807 & 807 & 807 & 807 & 807 & 807 & 807 & 807 & 807 & 807 & 807 & 807 & 807 & 807 \\
\hline
\end{tabular}

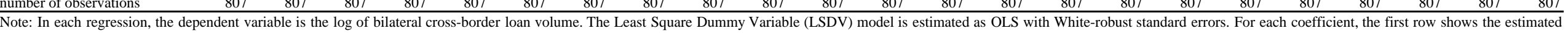

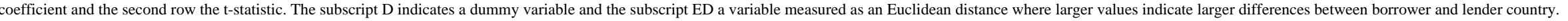


Table A4: LSDV model selectio

\begin{tabular}{|c|c|c|c|c|c|c|c|c|c|c|c|c|c|c|c|c|c|c|c|c|c|c|c|}
\hline & & & & & & & & & & & & & & & & & & & & & & & \\
\hline \multirow{2}{*}{ constant } & $\frac{\operatorname{Reg} 1}{12.84}$ & $\frac{\operatorname{Reg} 2}{13.94}$ & Reg 3 & Reg 4 & Reg 5 & Reg 6 & Reg 7 & Reg 8 & Reg 9 & Reg 10 & Reg 11 & Reg 12 & Reg 13 & Reg 14 & Reg 15 & Reg 16 & Reg 17 & Reg 18 & Reg 19 & Reg 20 & Reg 21 & Reg 22 & Reg 23 \\
\hline & 2.18 & 2.32 & 2.52 & $\begin{array}{r}11.100 \\
2.02\end{array}$ & 2.17 & $\begin{array}{r}13.20 \\
2.26\end{array}$ & $\begin{array}{r}13.31 \\
2.28\end{array}$ & $\begin{array}{r}13.39 \\
2.30\end{array}$ & $\begin{array}{r}13.23 \\
2.33\end{array}$ & 2.07 & $\begin{array}{r}12.01 \\
2.18\end{array}$ & $\begin{array}{r}2.04 \\
2.18\end{array}$ & $\begin{array}{r}13.15 \\
2.23\end{array}$ & $\begin{array}{r}2.00 \\
2.18\end{array}$ & $\begin{array}{r}2.10 \\
2.16\end{array}$ & $\begin{array}{r}13 . / 10 \\
2.38\end{array}$ & $\begin{array}{r}13.02 \\
2.21\end{array}$ & $\begin{array}{r}11.92 \\
2.11\end{array}$ & $\begin{array}{r}12.20 \\
2.20\end{array}$ & $\begin{array}{r}10.87 \\
1.99\end{array}$ & $\begin{array}{r}12.26 \\
2.34\end{array}$ & $\begin{array}{r}11.25 \\
2.09\end{array}$ & $\begin{array}{r}22.22 \\
2.33\end{array}$ \\
\hline \multirow[t]{2}{*}{ SIZE } & -0.45 & -0.61 & -0.66 & -0.29 & -0.45 & -0.49 & -0.49 & -0.49 & -0.42 & -0.46 & -0.42 & -0.45 & -0.45 & -0.45 & -0.44 & -0.54 & -0.46 & -0.48 & -0.44 & -0.24 & -0.36 & -0.27 & -0.36 \\
\hline & -0.42 & -0.56 & -0.62 & -0.27 & -0.42 & -0.46 & -0.46 & -0.46 & -0.41 & -0.45 & -0.39 & -0.42 & -0.42 & -0.42 & -0.41 & -0.51 & -0.43 & -0.47 & -0.44 & -0.24 & -0.38 & -0.28 & -0.38 \\
\hline \multirow[t]{2}{*}{ SIMILAR_GDP } & -0.24 & -0.32 & -0.35 & -0.09 & -0.24 & -0.25 & -0.24 & -0.24 & -0.15 & -0.21 & -0.22 & -0.24 & -0.24 & -0.24 & -0.23 & -0.29 & -0.24 & -0.21 & -0.14 & 0.05 & -0.02 & 0.04 & -0.02 \\
\hline & -0.44 & -0.58 & -0.65 & -0.16 & -0.44 & -0.46 & -0.45 & -0.45 & -0.29 & -0.40 & -0.41 & -0.44 & -0.44 & -0.44 & -0.44 & -0.55 & -0.44 & -0.41 & -0.28 & 0.09 & -0.04 & 0.09 & -0.04 \\
\hline \multirow[t]{2}{*}{ REL_GDP } & 0.75 & 0.73 & 0.72 & 0.80 & 0.74 & 0.95 & 0.86 & 0.93 & 0.73 & 0.80 & 0.68 & 0.75 & 0.70 & 0.75 & 0.80 & 0.58 & 0.72 & 0.87 & 0.77 & 0.84 & 0.58 & 0.70 & 0.59 \\
\hline & 2.60 & 2.54 & 2.51 & 2.73 & 2.54 & 3.30 & 2.98 & 3.22 & 2.60 & 2.79 & 2.32 & 2.59 & 2.40 & 2.56 & 2.75 & 2.12 & 2.46 & 3.05 & 2.77 & 2.95 & 2.19 & 2.51 & 2.27 \\
\hline \multirow[t]{2}{*}{ In(DISTANCE) } & -0.65 & -0.65 & -0.65 & -0.66 & -0.65 & -0.67 & -0.68 & -0.69 & -0.73 & -0.55 & -0.67 & -0.65 & -0.68 & -0.65 & -0.65 & -0.65 & -0.66 & -0.57 & -0.63 & -0.63 & -0.65 & -0.63 & -0.65 \\
\hline & -6.19 & -6.20 & -6.19 & -6.24 & -5.32 & -6.41 & -6.46 & -6.54 & -6.89 & -5.16 & -6.59 & -6.33 & -6.62 & -6.11 & -6.12 & -6.49 & -6.53 & -5.32 & -5.82 & -5.89 & -6.42 & -5.99 & -6.43 \\
\hline \multirow[t]{2}{*}{ BORDER $_{\mathrm{D}}$} & 0.53 & 0.53 & 0.53 & 0.51 & 0.52 & 0.46 & 0.46 & 0.46 & 0.47 & 0.49 & 0.53 & 0.53 & 0.51 & 0.53 & 0.52 & 0.55 & 0.53 & 0.47 & 0.46 & 0.43 & 0.45 & 0.44 & 0.45 \\
\hline & 5.48 & 5.49 & 5.49 & 5.25 & 5.39 & 4.78 & 4.74 & 4.74 & 4.99 & 5.39 & 5.49 & 5.42 & 5.35 & 5.31 & 5.31 & 5.75 & 5.42 & 5.14 & 5.03 & 4.71 & 5.03 & 4.77 & 5.04 \\
\hline $\ln \left(\right.$ FRGBNK $\left._{\text {bank country }}\right)$ & & $\begin{array}{l}-0.09 \\
-1.14\end{array}$ & & & & & & & & & & & & & & & & & & & & & \\
\hline $\ln \left(\right.$ FRGBNK $\left._{\text {customer country }}\right)$ & & & $\begin{array}{l}-0.15 \\
-1.99\end{array}$ & & & & & & & & & & & & & & & & & & & & \\
\hline \multirow[t]{2}{*}{$\ln \left(\mathrm{FRGBNK}_{\mathrm{ED}}\right)$} & & & & 0.08 & & & & & & & & & & & & & & & & 0.10 & 0.10 & 0.10 & 0.10 \\
\hline & & & & 2.16 & & & & & & & & & & & & & & & & 2.84 & 2.66 & 2.67 & 2.69 \\
\hline \multirow[t]{2}{*}{ LANGUAGE $_{\mathrm{D}}$} & & & & & 0.02 & & & & & & & & & & & & & & & & & & \\
\hline & & & & & 0.12 & & & & & & & & & & & & & & & & & & \\
\hline \multirow[t]{2}{*}{$\left.\ln \left(C_{L U T U R E}\right)_{\mathrm{ED}}\right)$} & & & & & & -0.35 & & & & & & & & & & & & -0.14 & & & & & \\
\hline & & & & & & -3.69 & & & & & & & & & & & & -1.40 & & & & & \\
\hline \multirow[t]{2}{*}{$\ln \left(C U L T 3 \_T R U S T_{E D}\right)$} & & & & & & & -0.32 & & & & & & & & & & & & & & & & \\
\hline & & & & & & & -3.26 & & & & & & & & & & & & & & & & \\
\hline \multirow[t]{2}{*}{$\ln \left(\mathrm{CULT} 4\right.$ TRUST $\mathrm{ED}_{\mathrm{ED}}$ ) } & & & & & & & & -0.38 & & & & & & & & & & & & & & & \\
\hline & & & & & & & & -4.00 & & & & & & & & & & & & & & & \\
\hline $\ln \left(\right.$ TRUST $_{\mathrm{ED}}$ ) & & & & & & & & & -0.23 & & & & & & & & & & -0.19 & -0.20 & -0.25 & -0.23 & -0.24 \\
\hline & & & & & & & & & -5.27 & & & & & & & & & & -4.42 & -4.58 & -5.15 & -4.69 & -5.46 \\
\hline LEGALFAM $_{\mathrm{D}}$ & & & & & & & & & & 0.67 & & & & & & & & 0.62 & 0.57 & 0.58 & 0.56 & 0.62 & 0.56 \\
\hline & & & & & & & & & & 6.46 & & & & & & & & 5.78 & 5.55 & 5.64 & 5.35 & 5.82 & 5.44 \\
\hline $\ln \left(\mathrm{POL}_{\mathrm{ED}}\right)$ & & & & & & & & & & & 0.06 & & & & & & & & & & & & \\
\hline & & & & & & & & & & & 0.76 & & & & & & & & & & & & \\
\hline $\ln \left(\mathrm{CORRUP}_{\mathrm{ED}}\right)$ & & & & & & & & & & & & 0.00 & & & & & & & & & & & \\
\hline & & & & & & & & & & & & -0.11 & & & & & & & & & & & \\
\hline $\ln \left(\mathrm{GOVEFF}_{\mathrm{ED}}\right)$ & & & & & & & & & & & & & 0.05 & & & & & & & & & & \\
\hline & & & & & & & & & & & & & 1.36 & & & & & & & & & & \\
\hline $\ln \left(\mathrm{POLSTAB}_{\mathrm{ED}}\right)$ & & & & & & & & & & & & & & 0.00 & & & & & & & & & \\
\hline & & & & & & & & & & & & & & -0.08 & & & & & & & & & \\
\hline $\ln \left(\mathrm{REGQAL}_{\mathrm{ED}}\right)$ & & & & & & & & & & & & & & & -0.03 & & & & & & 0.02 & 0.08 & \\
\hline & & & & & & & & & & & & & & & -0.84 & & & & & & 0.37 & 1.87 & \\
\hline $\ln \left(\mathrm{VOICE}_{\mathrm{ED}}\right)$ & & & & & & & & & & & & & & & & 0.12 & & & & & 0.16 & & 0.16 \\
\hline & & & & & & & & & & & & & & & & 3.40 & & & & & 4.37 & & 4.67 \\
\hline $\ln \left(\mathrm{LAW}_{\mathrm{ED}}\right)$ & & & & & & & & & & & & & & & & & 0.02 & & & & & & \\
\hline & & & & & & & & & & & & & & & & & 0.55 & & & & & & \\
\hline country lender dummies & Yes & Yes & Yes & Yes & Yes & Yes & Yes & Yes & Yes & Yes & Yes & Yes & Yes & Yes & Yes & Yes & Yes & Yes & Yes & Yes & Yes & Yes & Yes \\
\hline country $y_{\text {borrower }}$ dummies & Yes & Yes & Yes & Yes & Yes & Yes & Yes & Yes & Yes & Yes & Yes & Yes & Yes & Yes & Yes & Yes & Yes & Yes & Yes & Yes & Yes & Yes & Yes \\
\hline year dummies & Yes & Yes & Yes & Yes & Yes & Yes & Yes & Yes & Yes & Yes & Yes & Yes & Yes & Yes & Yes & Yes & Yes & Yes & Yes & Yes & Yes & Yes & Yes \\
\hline adjusted $R^{2}$ & 0.830 & 0.830 & 0.831 & 0.831 & 0.830 & 0.832 & 0.831 & 0.832 & 0.835 & 0.836 & 0.830 & 0.830 & 0.830 & 0.830 & 0.830 & 0.832 & 0.830 & 0.836 & 0.839 & 0.841 & 0.844 & 0.841 & 0.844 \\
\hline number of observations & 842 & 842 & 842 & 842 & 842 & 842 & 842 & 842 & 842 & 842 & 842 & 842 & 842 & 842 & 842 & 842 & 842 & 842 & 842 & 842 & 842 & 842 & 842 \\
\hline
\end{tabular}


Table A4: LSDV model selectior

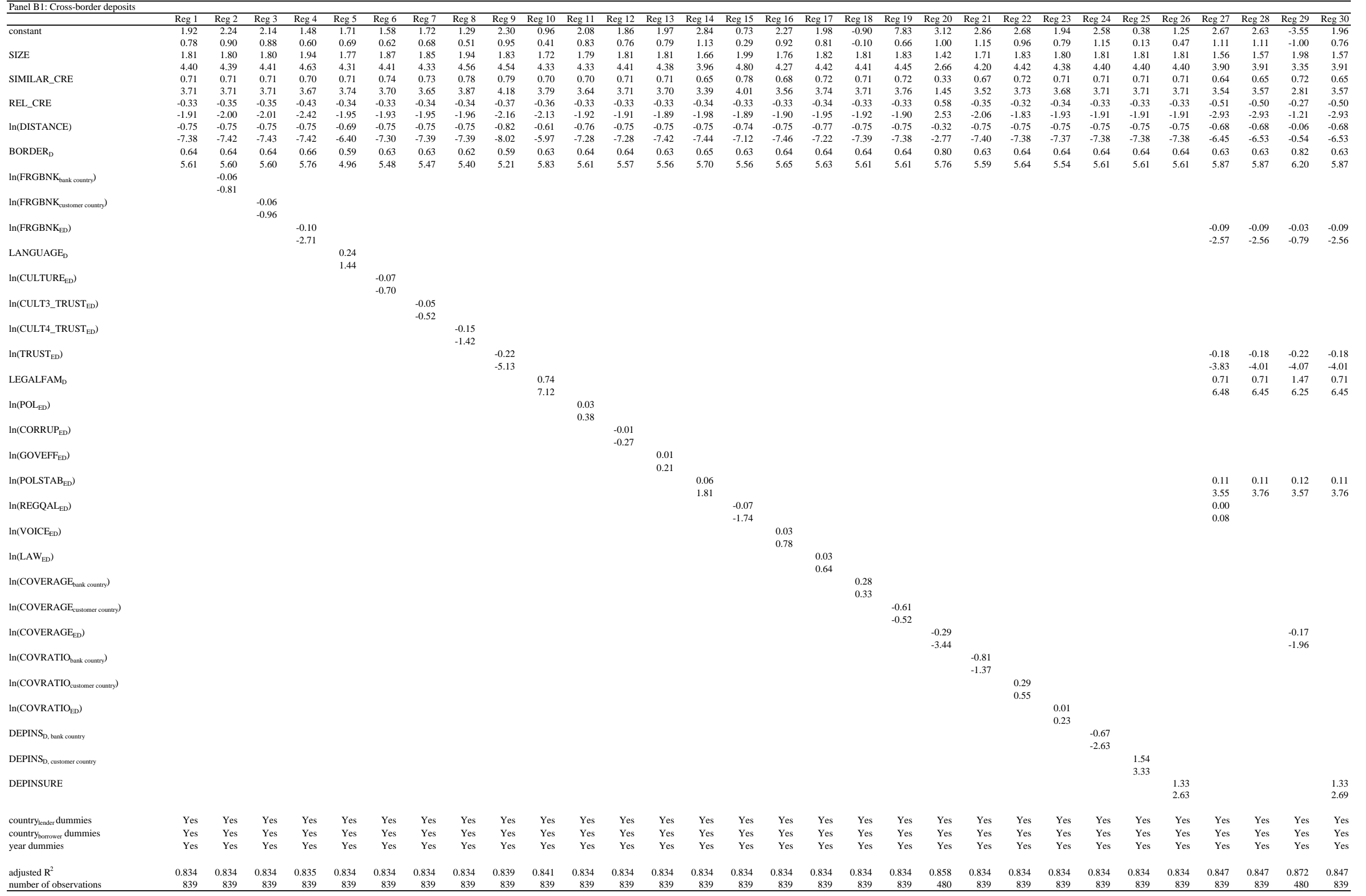


Table A4: LSDV model selection

\begin{tabular}{|c|c|c|c|c|c|c|c|c|c|c|c|c|c|c|c|c|c|c|c|c|c|c|c|c|c|c|c|c|c|c|}
\hline \multirow{3}{*}{ constant } & Reg 1 & $\operatorname{Reg} 2$ & $\operatorname{Reg} 3$ & Reg 4 & Reg 5 & Reg 6 & Reg 7 & Reg 8 & Reg 9 & Reg 10 & Reg 11 & Reg 12 & Reg 13 & Reg 14 & Reg 15 & Reg 16 & Reg 17 & Reg 18 & Reg 19 & $\operatorname{Reg} 20$ & Reg 21 & Reg 22 & $\operatorname{Reg} 23$ & Reg 24 & Reg 25 & $\operatorname{Reg} 26$ & $\operatorname{Reg} 27$ & $\operatorname{Reg} 28$ & Reg 29 & Reg 30 \\
\hline & 2.96 & 3.29 & 3.37 & 3.81 & 2.84 & 3.14 & 3.08 & 3.30 & 3.46 & 1.69 & 2.98 & 2.94 & 2.96 & 2.61 & 2.53 & 3.20 & 2.78 & 7.42 & 8.01 & 7.83 & 5.29 & 2.08 & 3.06 & 3.68 & 2.04 & 2.25 & 1.99 & 2.11 & 3.37 & 1.32 \\
\hline & 0.44 & 0.48 & 0.50 & 0.57 & 0.42 & 0.47 & 0.46 & 0.49 & 0.54 & 0.25 & 0.44 & 0.44 & 0.44 & 0.39 & 0.38 & 0.48 & 0.41 & 0.70 & 0.62 & 0.90 & 0.76 & 0.31 & 0.45 & 0.60 & 0.25 & 0.31 & 0.31 & 0.33 & 0.40 & 0.19 \\
\hline \multirow{2}{*}{ SIZE } & 1.60 & 1.56 & 1.54 & 1.47 & 1.60 & 1.58 & 1.59 & 1.58 & 1.61 & 1.58 & 1.59 & 1.59 & 1.60 & 1.68 & 1.64 & 1.58 & 1.60 & 1.60 & 1.69 & 0.49 & 1.21 & 2.02 & 1.59 & 1.60 & 1.60 & 1.60 & 1.65 & 1.63 & 0.65 & 1.63 \\
\hline & 1.30 & 1.27 & 1.26 & 1.21 & 1.30 & 1.28 & 1.30 & 1.29 & 1.37 & 1.30 & 1.29 & 1.29 & 1.30 & 1.36 & 1.35 & 1.28 & 1.30 & 1.30 & 1.38 & 0.31 & 0.96 & 1.57 & 1.29 & 1.30 & 1.30 & 1.30 & 1.42 & 1.41 & 0.44 & 1.41 \\
\hline \multirow[t]{2}{*}{ SIMILAR_GDP } & 0.64 & 0.62 & 0.61 & 0.52 & 0.65 & 0.63 & 0.64 & 0.64 & 0.71 & 0.68 & 0.63 & 0.64 & 0.64 & 0.69 & 0.66 & 0.62 & 0.64 & 0.64 & 0.68 & -0.12 & 0.44 & 0.85 & 0.63 & 0.64 & 0.64 & 0.64 & 0.74 & 0.73 & 0.13 & 0.73 \\
\hline & 1.02 & 0.98 & 0.97 & 0.84 & 1.03 & 1.01 & 1.02 & 1.02 & 1.19 & 1.09 & 1.01 & 1.01 & 1.02 & 1.10 & 1.06 & 0.99 & 1.02 & 1.02 & 1.09 & -0.14 & 0.69 & 1.29 & 1.01 & 1.02 & 1.02 & 1.02 & 1.26 & 1.25 & 0.17 & 1.25 \\
\hline \multirow[t]{2}{*}{ REL_GDP } & 0.88 & 0.87 & 0.87 & 0.86 & 0.87 & 1.01 & 0.92 & 1.03 & 0.91 & 0.99 & 0.89 & 0.89 & 0.88 & 0.81 & 0.99 & 0.85 & 0.91 & 0.88 & 0.87 & 0.00 & 0.89 & 0.86 & 0.89 & 0.88 & 0.88 & 0.88 & 0.87 & 0.86 & 0.29 & 0.86 \\
\hline & 4.03 & 4.02 & 4.01 & 3.99 & 3.96 & 4.39 & 4.14 & 4.52 & 4.42 & 4.54 & 3.96 & 4.07 & 3.96 & 3.80 & 4.48 & 3.97 & 4.09 & 4.04 & 4.01 & 0.00 & 4.09 & 3.98 & 4.08 & 4.03 & 4.03 & 4.03 & 4.36 & 4.32 & 1.41 & 4.32 \\
\hline \multirow[t]{2}{*}{$\ln$ (DISTANCE) } & -0.84 & -0.84 & -0.84 & -0.84 & -0.82 & -0.86 & -0.85 & -0.87 & -0.92 & -0.73 & -0.84 & -0.83 & -0.84 & -0.84 & -0.84 & -0.85 & -0.83 & -0.84 & -0.84 & -0.30 & -0.84 & -0.84 & -0.84 & -0.84 & -0.84 & -0.84 & -0.78 & -0.79 & -0.11 & -0.79 \\
\hline & -8.17 & -8.16 & -8.16 & -8.15 & -7.46 & -8.28 & -8.19 & -8.35 & -8.85 & -7.08 & -7.98 & -8.03 & -8.14 & -8.17 & -8.05 & -8.26 & -7.79 & -8.18 & -8.16 & -2.46 & -8.22 & -8.15 & -8.21 & -8.17 & -8.17 & -8.17 & -7.37 & -7.45 & -0.85 & -7.45 \\
\hline \multirow[t]{2}{*}{ BORDER $_{\mathrm{D}}$} & 0.56 & 0.56 & 0.56 & 0.57 & 0.54 & 0.52 & 0.54 & 0.52 & 0.51 & 0.54 & 0.56 & 0.55 & 0.56 & 0.57 & 0.55 & 0.56 & 0.55 & 0.56 & 0.56 & 0.76 & 0.56 & 0.56 & 0.55 & 0.56 & 0.56 & 0.56 & 0.54 & 0.54 & 0.81 & 0.54 \\
\hline & 4.99 & $\begin{array}{r}4.99 \\
-0.03\end{array}$ & 4.99 & 5.13 & 4.50 & 4.59 & 4.70 & 4.54 & 4.57 & 5.04 & 4.99 & 4.93 & 4.97 & 5.07 & 4.91 & 5.04 & 4.90 & 4.99 & 4.99 & 5.56 & 5.00 & 5.00 & 4.77 & 4.99 & 4.99 & 4.99 & 5.04 & 5.03 & 6.20 & 5.03 \\
\hline $\ln ($ FRGBNK bank country) & & $\begin{array}{l}-0.03 \\
-0.36\end{array}$ & & & & & & & & & & & & & & & & & & & & & & & & & & & & \\
\hline $\ln \left(\mathrm{FRGBNK}_{\text {customer country }}\right)$ & & & $\begin{array}{l}-0.04 \\
-0.57\end{array}$ & & & & & & & & & & & & & & & & & & & & & & & & & & & \\
\hline $\ln \left(\mathrm{FRGBNK}_{\mathrm{ED}}\right)$ & & & & -0.07 & & & & & & & & & & & & & & & & & & & & & & & -0.05 & -0.05 & 0.01 & -0.05 \\
\hline LANGUAGE & & & & -2.05 & & & & & & & & & & & & & & & & & & & & & & & -1.62 & -1.65 & 0.20 & -1.65 \\
\hline LANGUAGE & & & & & 0.41 & & & & & & & & & & & & & & & & & & & & & & & & & \\
\hline $\ln ($ CULTUREED) & & & & & & $\begin{array}{l}-0.19 \\
-1.67\end{array}$ & & & & & & & & & & & & & & & & & & & & & & & & \\
\hline $\ln ($ CULT3_TRUST & & & & & & & -0.09 & & & & & & & & & & & & & & & & & & & & & & & \\
\hline JPCUUTA TRUIST & & & & & & & -0.83 & & & & & & & & & & & & & & & & & & & & & & & \\
\hline 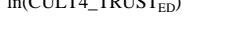 & & & & & & & & $\begin{array}{l}-0.23 \\
-2.09\end{array}$ & & & & & & & & & & & & & & & & & & & & & & \\
\hline $\ln \left(\right.$ TRUST $\left._{\mathrm{ED}}\right)$ & & & & & & & & & -0.22 & & & & & & & & & & & & & & & & & & -0.16 & -0.17 & -0.16 & -0.17 \\
\hline & & & & & & & & & -5.06 & & & & & & & & & & & & & & & & & & -3.56 & -3.93 & -3.59 & -3.93 \\
\hline LEGALFAM $_{\mathrm{D}}$ & & & & & & & & & & 0.78 & & & & & & & & & & & & & & & & & 0.74 & 0.75 & 1.40 & 0.75 \\
\hline & & & & & & & & & & 7.74 & & & & & & & & & & & & & & & & & 6.78 & 6.82 & 6.36 & 6.82 \\
\hline $\ln \left(\mathrm{POL}_{\mathrm{ED}}\right)$ & & & & & & & & & & & $\begin{array}{l}-0.02 \\
-0.30\end{array}$ & & & & & & & & & & & & & & & & & & & \\
\hline $\ln \left(\mathrm{CORRUP}_{\mathrm{ED}}\right)$ & & & & & & & & & & & & -0.02 & & & & & & & & & & & & & & & & & & \\
\hline & & & & & & & & & & & & -0.63 & & & & & & & & & & & & & & & & & & \\
\hline $\ln \left(\mathrm{GOVEFF}_{\mathrm{ED}}\right)$ & & & & & & & & & & & & & 0.00 & & & & & & & & & & & & & & & & & \\
\hline $\ln \left(\right.$ POLSTAB $\left._{\mathrm{ED}}\right)$ & & & & & & & & & & & & & & 0.05 & & & & & & & & & & & & & 0.11 & 0.10 & 0.13 & 0.10 \\
\hline (2) & & & & & & & & & & & & & & 1.74 & & & & & & & & & & & & & 3.63 & 3.70 & 3.86 & 3.70 \\
\hline $\ln \left(\mathrm{REGQAL}_{\mathrm{ED}}\right)$ & & & & & & & & & & & & & & & -0.08 & & & & & & & & & & & & -0.01 & & & \\
\hline & & & & & & & & & & & & & & & -2.30 & & & & & & & & & & & & -0.37 & & & \\
\hline $\ln \left(\mathrm{VOICE}_{\mathrm{ED}}\right)$ & & & & & & & & & & & & & & & & 0.03 & & & & & & & & & & & & & & \\
\hline $\ln \left(\mathrm{LAW}_{\mathrm{ED}}\right)$ & & & & & & & & & & & & & & & & 1.00 & -0.03 & & & & & & & & & & & & & \\
\hline & & & & & & & & & & & & & & & & & $\begin{array}{l}-0.03 \\
-0.77\end{array}$ & & & & & & & & & & & & & \\
\hline $\ln \left(\mathrm{COVVRAGE}_{\text {bank country }}\right)$ & & & & & & & & & & & & & & & & & & -0.44 & & & & & & & & & & & & \\
\hline & & & & & & & & & & & & & & & & & & -0.51 & & & & & & & & & & & & \\
\hline $\ln (\mathrm{COVERAGE}$ ustomer country) & & & & & & & & & & & & & & & & & & & -0.56 & & & & & & & & & & & \\
\hline $\ln \left(\mathrm{COVERAGE}_{\mathrm{FD}}\right)$ & & & & & & & & & & & & & & & & & & & & -0.23 & & & & & & & & & -0.11 & \\
\hline & & & & & & & & & & & & & & & & & & & & -2.80 & & & & & & & & & -1.29 & \\
\hline $\ln \left(C_{1}\right.$ RATIO bank country $)$ & & & & & & & & & & & & & & & & & & & & & $\begin{array}{l}-0.40 \\
-0.92\end{array}$ & & & & & & & & & \\
\hline $\ln \left(\right.$ COVRATIO $\left._{\text {customer country }}\right)$ & & & & & & & & & & & & & & & & & & & & & & 0.45 & & & & & & & & \\
\hline & & & & & & & & & & & & & & & & & & & & & & 1.11 & & & & & & & & \\
\hline $\ln ($ COVRATIO ED $)$ & & & & & & & & & & & & & & & & & & & & & & & $\begin{array}{l}-0.01 \\
-0.31\end{array}$ & & & & & & & \\
\hline DEPINS $_{\mathrm{D}, \text { bank county }}$ & & & & & & & & & & & & & & & & & & & & & & & & $\begin{array}{l}-0.71 \\
-0.11\end{array}$ & & & & & & \\
\hline DEPINS $_{\mathrm{D}, \text { customer country }}$ & & & & & & & & & & & & & & & & & & & & & & & & & 0.93 & & & & & \\
\hline DEPINSURE & & & & & & & & & & & & & & & & & & & & & & & & & 0.61 & $\begin{array}{l}1.43 \\
1.11\end{array}$ & & & & $\begin{array}{l}1.57 \\
1.29\end{array}$ \\
\hline country len $_{\text {n }}$ & Yes & Yes & Yes & Yes & Yes & Yes & Yes & Yes & Yes & Yes & Yes & Yes & Yes & Yes & Yes & Yes & Yes & Yes & Yes & Yes & Yes & Yes & Yes & Yes & Yes & Yes & Yes & Yes & Yes & Yes \\
\hline country borrower dummies & Yes & Yes & Yes & Yes & Yes & Yes & Yes & Yes & Yes & Yes & Yes & Yes & Yes & Yes & Yes & Yes & Yes & Yes & Yes & Yes & Yes & Yes & Yes & Yes & Yes & Yes & Yes & Yes & Yes & Yes \\
\hline year dummies & Yes & Yes & Yes & Yes & Yes & Yes & Yes & Yes & Yes & Yes & Yes & Yes & Yes & Yes & Yes & Yes & Yes & Yes & Yes & Yes & Yes & Yes & Yes & Yes & Yes & Yes & Yes & Yes & Yes & Yes \\
\hline adjusted $R^{2}$ & 0.835 & 0.835 & 0.835 & 0.836 & 0.835 & 0.836 & 0.835 & 0.836 & 0.840 & 0.843 & 0.835 & 0.835 & 0.835 & 0.835 & 0.836 & 0.835 & 0.835 & 0.835 & 0.835 & 0.863 & 0.835 & 0.835 & 0.835 & 0.835 & 0.835 & 0.835 & 0.847 & 0.847 & 0.878 & 0.847 \\
\hline number of obser & 877 & 877 & 877 & 877 & 877 & 877 & 877 & 877 & 877 & 877 & 877 & 877 & 877 & 877 & 877 & 877 & 877 & 877 & 877 & 496 & 877 & 877 & 877 & 877 & 877 & 877 & 877 & 877 & 496 & 877 \\
\hline
\end{tabular}


Table A5: Robustness check for LSDV model selection

Panel A1: Cross-border loans

\begin{tabular}{|c|c|c|c|c|c|c|c|c|c|c|c|c|c|c|c|c|c|c|c|c|c|c|c|}
\hline & Reg 1 & Reg 2 & Reg 3 & Reg 6 & Reg 7 & Reg 4 & Reg 5 & Reg 8 & Reg 9 & Reg 10 & Reg 11 & Reg 12 & Reg 13 & Reg 14 & Reg 15 & Reg 16 & Reg 17 & Reg 18 & Reg 19 & Reg 20 & Reg 21 & Reg 22 & Reg 23 \\
\hline \multirow[t]{2}{*}{ constant } & -3.03 & $\begin{array}{l}-2.82 \\
\end{array}$ & -2.30 & $\begin{array}{l}-2.72 \\
\end{array}$ & -3.03 & -3.89 & -3.30 & -3.66 & $\begin{array}{l}-1.44 \\
\end{array}$ & -2.57 & -2.81 & -3.12 & -2.89 & -3.17 & -3.26 & -1.86 & -3.18 & -2.95 & -1.27 & -0.88 & 1.06 & -0.06 & 0.98 \\
\hline & -1.05 & -0.97 & -0.80 & -0.97 & -1.06 & -1.33 & -1.14 & -1.26 & -0.49 & -0.90 & -0.98 & -1.09 & -1.00 & -1.09 & -1.13 & -0.65 & -1.11 & -1.00 & -0.44 & -0.31 & 0.37 & -0.02 & 0.35 \\
\hline \multirow[t]{2}{*}{ SIZE } & 0.98 & 0.98 & 0.98 & 0.84 & 0.98 & 1.21 & 1.15 & 1.25 & 1.07 & 0.95 & 0.91 & 0.96 & 0.96 & 1.01 & 1.05 & 0.79 & 1.01 & 1.04 & 1.02 & 0.87 & 0.61 & 0.71 & 0.63 \\
\hline & 2.24 & 2.23 & 2.24 & 1.94 & 2.24 & 2.60 & 2.46 & 2.66 & 2.42 & 2.18 & 2.00 & 2.16 & 2.17 & 2.20 & 2.22 & 1.77 & 2.30 & 2.26 & 2.34 & 2.03 & 1.34 & 1.56 & 1.46 \\
\hline \multirow[t]{2}{*}{ SIMILAR_CRE } & 0.41 & 0.41 & 0.41 & 0.43 & 0.41 & 0.52 & 0.50 & 0.55 & 0.50 & 0.42 & 0.39 & 0.40 & 0.41 & 0.42 & 0.44 & 0.32 & 0.43 & 0.46 & 0.49 & 0.51 & 0.41 & 0.46 & 0.41 \\
\hline & 1.84 & 1.84 & 1.85 & 1.92 & 1.84 & 2.19 & 2.06 & 2.27 & 2.18 & 1.86 & 1.67 & 1.76 & 1.81 & 1.83 & 1.84 & 1.43 & 1.94 & 1.95 & 2.15 & 2.24 & 1.73 & 1.93 & 1.82 \\
\hline \multirow[t]{2}{*}{ REL_CRE } & 0.33 & 0.31 & 0.30 & 0.45 & 0.33 & 0.34 & 0.32 & 0.34 & 0.32 & 0.34 & 0.32 & 0.32 & 0.34 & 0.33 & 0.33 & 0.34 & 0.31 & 0.35 & 0.34 & 0.46 & 0.47 & 0.45 & 0.48 \\
\hline & 1.50 & 1.44 & 1.38 & 1.94 & 1.50 & 1.55 & 1.47 & 1.52 & 1.49 & 1.57 & 1.43 & 1.44 & 1.56 & 1.50 & 1.51 & 1.58 & 1.37 & 1.59 & 1.55 & 2.03 & 2.12 & 1.99 & 2.13 \\
\hline \multirow[t]{2}{*}{$\ln$ (DISTANCE) } & -0.08 & -0.09 & -0.09 & -0.06 & -0.08 & -0.09 & -0.12 & -0.13 & -0.24 & -0.07 & -0.09 & -0.08 & -0.09 & -0.09 & -0.09 & -0.08 & -0.10 & -0.07 & -0.21 & -0.19 & -0.22 & -0.18 & -0.22 \\
\hline & -0.56 & -0.59 & -0.64 & -0.43 & -0.55 & -0.64 & -0.80 & -0.87 & -1.56 & -0.47 & -0.61 & -0.54 & -0.65 & -0.58 & -0.59 & -0.56 & -0.68 & -0.51 & -1.35 & -1.26 & -1.49 & -1.24 & -1.51 \\
\hline \multirow[t]{2}{*}{ BORDER $_{\mathrm{D}}$} & 0.29 & 0.29 & 0.29 & 0.28 & 0.29 & 0.26 & 0.27 & 0.27 & 0.30 & 0.32 & 0.28 & 0.28 & 0.26 & 0.29 & 0.29 & 0.30 & 0.28 & 0.30 & 0.32 & 0.31 & 0.32 & 0.30 & 0.32 \\
\hline & 2.54 & 2.52 & 2.52 & 2.42 & 2.58 & 2.30 & 2.40 & 2.38 & 2.70 & 2.86 & 2.40 & 2.45 & 2.24 & 2.52 & 2.55 & 2.67 & 2.50 & 2.74 & 2.98 & 2.85 & 3.03 & 2.84 & 3.04 \\
\hline \multirow[t]{2}{*}{$\ln \left(\right.$ FRGBNK $\left._{\text {bank country }}\right)$} & & -0.06 & & & & & & & & & & & & & & & & & & & & & \\
\hline & & -0.75 & & & & & & & & & & & & & & & & & & & & & \\
\hline \multirow[t]{2}{*}{$\ln \left(\right.$ FRGBNK $\left._{\text {customer country }}\right)$} & & & -0.12 & & & & & & & & & & & & & & & & & & & & \\
\hline & & & -1.66 & & & & & & & & & & & & & & & & & 0.13 & 0.13 & 0.13 & 0.13 \\
\hline \multirow[t]{2}{*}{$\ln \left(\mathrm{FRGBNK}_{\mathrm{ED}}\right)$} & & & & 0.12 & & & & & & & & & & & & & & & & 3.44 & 3.49 & 3.37 & 3.51 \\
\hline & & & & 3.11 & & & & & & & & & & & & & & & & & & & \\
\hline \multirow[t]{2}{*}{ LANGUAGE $_{D}$} & & & & & 0.00 & & & & & & & & & & & & & & & & & & \\
\hline & & & & & 0.03 & & & & & & & & & & & & & & & & & & \\
\hline \multirow[t]{2}{*}{$\ln \left(\mathrm{CULTURE}_{\mathrm{ED}}\right)$} & & & & & & -0.28 & & & & & & & & & & & & -0.11 & & & & & \\
\hline & & & & & & -2.70 & & & & & & & & & & & & -1.08 & & & & & \\
\hline $\ln \left(T R U S T \& C U L T U R E_{3, \mathrm{ED}}\right)$ & & & & & & & -0.19 & & & & & & & & & & & & & & & & \\
\hline $\ln \left(T_{R U S T \& C U L T U R E}^{4, \mathrm{ED}}\right)$ & & & & & & & -1.77 & -0.29 & & & & & & & & & & & & & & & \\
\hline & & & & & & & & -2.74 & & & & & & & & & & & & & & & \\
\hline $\ln \left(\mathrm{TRUST}_{\mathrm{ED}}\right)$ & & & & & & & & & -0.18 & & & & & & & & & & -0.15 & -0.16 & -0.20 & -0.18 & -0.19 \\
\hline & & & & & & & & & -3.40 & & & & & & & & & & -3.02 & -3.16 & -3.68 & -3.31 & -3.78 \\
\hline LEGALFAM $_{\mathrm{D}}$ & & & & & & & & & & 0.54 & & & & & & & & 0.50 & 0.49 & 0.49 & 0.49 & 0.53 & 0.48 \\
\hline & & & & & & & & & & 4.84 & & & & & & & & 4.46 & 4.52 & 4.59 & 4.44 & 4.76 & 4.49 \\
\hline $\ln \left(\mathrm{POL}_{\mathrm{ED}}\right)$ & & & & & & & & & & & 0.09 & & & & & & & & & & & & \\
\hline & & & & & & & & & & & 1.11 & & & & & & & & & & & & \\
\hline $\ln \left(\mathrm{CORRUP}_{\mathrm{ED}}\right)$ & & & & & & & & & & & & 0.04 & & & & & & & & & & & \\
\hline & & & & & & & & & & & & 1.30 & & & & & & & & & & & \\
\hline $\ln \left(G O V E F F_{E D}\right)$ & & & & & & & & & & & & & 0.06 & & & & & & & & & & \\
\hline & & & & & & & & & & & & & 1.55 & & & & & & & & & & \\
\hline $\ln \left(\mathrm{POLSTAB}_{\mathrm{ED}}\right)$ & & & & & & & & & & & & & & -0.01 & & & & & & & & & \\
\hline & & & & & & & & & & & & & & -0.33 & & & & & & & & & \\
\hline $\ln \left(\mathrm{REGQAL}_{\mathrm{ED}}\right)$ & & & & & & & & & & & & & & & -0.02 & & & & & & 0.01 & 0.06 & \\
\hline & & & & & & & & & & & & & & & -0.54 & & & & & & 0.18 & 1.33 & \\
\hline $\ln \left(\mathrm{VOICE}_{\mathrm{ED}}\right)$ & & & & & & & & & & & & & & & & 0.10 & & & & & 0.14 & & 0.14 \\
\hline & & & & & & & & & & & & & & & & 2.84 & & & & & 3.50 & & 3.68 \\
\hline $\ln \left(\mathrm{LAW}_{\mathrm{ED}}\right)$ & & & & & & & & & & & & & & & & & 0.05 & & & & & & \\
\hline & & & & & & & & & & & & & & & & & 1.23 & & & & & & \\
\hline $\ln (\mathrm{TRADEVOL})$ & 0.66 & 0.66 & 0.65 & 0.67 & 0.66 & 0.63 & 0.62 & 0.61 & 0.52 & 0.55 & 0.69 & 0.70 & 0.68 & 0.65 & 0.64 & 0.67 & 0.69 & 0.54 & 0.44 & 0.45 & 0.45 & 0.46 & 0.44 \\
\hline & 4.02 & 4.04 & 3.99 & 4.19 & 3.97 & 3.86 & 3.69 & 3.66 & 3.05 & 3.32 & 3.98 & 4.00 & 4.10 & 3.96 & 3.74 & 4.14 & 4.04 & 3.31 & 2.59 & 2.70 & 2.72 & 2.79 & 2.74 \\
\hline country lender $_{\text {dummies }}$ & Yes & Yes & Yes & Yes & Yes & Yes & Yes & Yes & Yes & Yes & Yes & Yes & Yes & Yes & Yes & Yes & Yes & Yes & Yes & Yes & Yes & Yes & Yes \\
\hline country $_{\text {borrower }}$ dummies & Yes & Yes & Yes & Yes & Yes & Yes & Yes & Yes & Yes & Yes & Yes & Yes & Yes & Yes & Yes & Yes & Yes & Yes & Yes & Yes & Yes & Yes & Yes \\
\hline year dummies & Yes & Yes & Yes & Yes & Yes & Yes & Yes & Yes & Yes & Yes & Yes & Yes & Yes & Yes & Yes & Yes & Yes & Yes & Yes & Yes & Yes & Yes & Yes \\
\hline adjusted $R^{2}$ & 0.836 & 0.836 & 0.836 & 0.838 & 0.836 & 0.837 & 0.836 & 0.837 & 0.839 & 0.840 & 0.836 & 0.836 & 0.836 & 0.836 & 0.836 & 0.837 & 0.836 & 0.840 & 0.842 & 0.844 & 0.846 & 0.844 & 0.846 \\
\hline number of observations & 807 & 807 & 807 & 807 & 807 & 807 & 807 & 807 & 807 & 807 & 807 & 807 & 807 & 807 & 807 & 807 & 807 & 807 & 807 & 807 & 807 & 807 & 807 \\
\hline
\end{tabular}


Table A5: Robustness check for LSDV model selection Panel A2: Cross-border loans

\begin{tabular}{|c|c|c|c|c|c|c|c|c|c|c|c|c|c|c|c|c|c|c|c|c|c|c|c|}
\hline & Reg 1 & Reg 2 & Reg 3 & Reg 6 & Reg 7 & Reg 4 & Reg 5 & Reg 8 & Reg 9 & Reg 10 & Reg 11 & Reg 12 & Reg 13 & Reg 14 & Reg 15 & Reg 16 & Reg 17 & Reg 18 & Reg 19 & Reg 20 & Reg 21 & Reg 22 & $\operatorname{Reg} 23$ \\
\hline \multirow[t]{2}{*}{ constant } & 10.27 & 11.49 & 12.07 & 8.90 & 10.37 & 10.66 & 10.79 & 10.91 & 11.20 & 9.80 & 9.95 & 10.18 & 10.55 & 10.18 & 10.27 & 11.07 & 10.58 & 10.02 & 10.64 & 9.13 & 10.49 & 9.46 & 10.46 \\
\hline & 1.69 & 1.85 & 2.00 & 1.48 & 1.70 & 1.76 & 1.78 & 1.80 & 1.89 & 1.67 & 1.63 & 1.67 & 1.73 & 1.66 & 1.69 & 1.86 & 1.75 & 1.71 & 1.84 & 1.61 & 1.93 & 1.70 & 1.92 \\
\hline \multirow[t]{2}{*}{ SIZE } & -1.08 & -1.27 & -1.28 & -0.92 & -1.09 & -1.11 & -1.07 & -1.07 & -0.91 & -0.96 & -1.06 & -1.10 & -1.13 & -1.07 & -1.08 & -1.21 & -1.14 & -0.98 & -0.83 & -0.65 & -0.79 & -0.71 & -0.78 \\
\hline & -1.07 & -1.24 & -1.27 & -0.92 & -1.08 & -1.11 & -1.06 & -1.07 & -0.92 & -0.98 & -1.05 & -1.09 & -1.11 & -1.05 & -1.07 & -1.22 & -1.13 & -1.00 & -0.86 & -0.68 & -0.86 & -0.75 & -0.84 \\
\hline \multirow[t]{2}{*}{ SIMILAR_GDP } & -0.52 & -0.61 & -0.62 & -0.36 & -0.53 & -0.52 & -0.50 & -0.50 & -0.38 & -0.43 & -0.50 & -0.52 & -0.54 & -0.51 & -0.52 & -0.59 & -0.54 & -0.44 & -0.33 & -0.14 & -0.21 & -0.15 & -0.21 \\
\hline & -1.02 & -1.19 & -1.22 & -0.70 & -1.03 & -1.03 & -0.99 & -0.99 & -0.76 & -0.87 & -0.98 & -1.04 & -1.05 & -0.99 & -1.02 & -1.18 & -1.07 & -0.89 & -0.67 & -0.29 & -0.45 & -0.32 & -0.45 \\
\hline \multirow[t]{2}{*}{ REL_GDP } & 0.81 & 0.79 & 0.77 & 0.87 & 0.82 & 0.99 & 0.89 & 0.96 & 0.78 & 0.84 & 0.66 & 0.78 & 0.74 & 0.79 & 0.81 & 0.62 & 0.72 & 0.92 & 0.81 & 0.88 & 0.60 & 0.73 & 0.63 \\
\hline & 2.76 & 2.70 & 2.68 & 2.90 & 2.75 & 3.45 & 3.07 & 3.31 & 2.74 & 2.90 & 2.21 & 2.64 & 2.50 & 2.64 & 2.73 & 2.26 & 2.43 & 3.21 & 2.87 & 3.06 & 2.28 & 2.58 & 2.40 \\
\hline \multirow[t]{2}{*}{ In(DISTANCE) } & -0.27 & -0.27 & -0.27 & -0.26 & -0.29 & -0.30 & -0.32 & -0.33 & -0.42 & -0.26 & -0.27 & -0.27 & -0.28 & -0.27 & -0.27 & -0.25 & -0.28 & -0.28 & -0.39 & -0.38 & -0.39 & -0.37 & -0.40 \\
\hline & -1.70 & -1.67 & -1.69 & -1.64 & -1.74 & -1.87 & -1.96 & -2.04 & -2.57 & -1.71 & -1.69 & -1.67 & -1.78 & -1.64 & -1.63 & -1.60 & -1.77 & -1.80 & -2.45 & -2.44 & -2.59 & -2.36 & -2.63 \\
\hline \multirow{2}{*}{ BORDER $_{\mathrm{D}}$} & 0.34 & 0.33 & 0.34 & 0.31 & 0.35 & 0.28 & 0.30 & 0.29 & 0.34 & 0.35 & 0.32 & 0.33 & 0.29 & 0.34 & 0.34 & 0.35 & 0.33 & 0.32 & 0.34 & 0.31 & 0.33 & 0.31 & 0.33 \\
\hline & 2.85 & 2.84 & 2.88 & 2.61 & 2.98 & 2.37 & 2.55 & 2.50 & 2.97 & 3.08 & 2.73 & 2.80 & 2.50 & 2.84 & 2.85 & 3.03 & 2.84 & 2.81 & 3.17 & 2.88 & 3.14 & 2.93 & 3.15 \\
\hline $\ln \left(\right.$ FRGBNK $\left._{\text {bank country }}\right)$ & & $\begin{array}{l}-0.10 \\
-1.34\end{array}$ & & & & & & & & & & & & & & & & & & & & & \\
\hline \multirow[t]{2}{*}{$\ln \left(\right.$ FRGBNK $\left._{\text {customer country }}\right)$} & & & -0.15 & & & & & & & & & & & & & & & & & & & & \\
\hline & & & -1.92 & & & & & & & & & & & & & & & & & 0.11 & 0.10 & 0.10 & 0.10 \\
\hline \multirow[t]{2}{*}{$\ln \left(\right.$ FRGBNK $\left._{\mathrm{ED}}\right)$} & & & & 0.10 & & & & & & & & & & & & & & & & 3.06 & 2.86 & 2.87 & 2.91 \\
\hline & & & & 2.60 & & & & & & & & & & & & & & & & & & & \\
\hline \multirow[t]{2}{*}{ LANGUAGE $_{\mathrm{D}}$} & & & & & -0.07 & & & & & & & & & & & & & & & & & & \\
\hline & & & & & -0.45 & & & & & & & & & & & & & & & & & & \\
\hline \multirow[t]{2}{*}{$\ln \left(\right.$ CULTURE $\left._{\mathrm{ED}}\right)$} & & & & & & -0.33 & & & & & & & & & & & & -0.15 & & & & & \\
\hline & & & & & & -3.59 & & & & & & & & & & & & -1.62 & & & & & \\
\hline $\ln \left(\right.$ TRUST\&CULTURE $_{3, \mathrm{ED}}$ ) & & & & & & & $\begin{array}{l}-0.25 \\
-2.55\end{array}$ & & & & & & & & & & & & & & & & \\
\hline $\ln \left(\right.$ TRUST\&CULTURE $\left._{4, \mathrm{ED}}\right)$ & & & & & & & & -0.33 & & & & & & & & & & & & & & & \\
\hline & & & & & & & & -3.45 & & & & & & & & & & & & & & & \\
\hline $\ln \left(\right.$ TRUST $\left._{\mathrm{ED}}\right)$ & & & & & & & & & -0.20 & & & & & & & & & & -0.16 & -0.17 & -0.22 & -0.20 & -0.22 \\
\hline & & & & & & & & & -3.94 & & & & & & & & & & -3.47 & -3.61 & -4.38 & -3.93 & -4.49 \\
\hline LEGALFAM $_{D}$ & & & & & & & & & & 0.59 & & & & & & & & 0.54 & 0.52 & 0.52 & 0.52 & 0.57 & 0.50 \\
\hline & & & & & & & & & & 5.21 & & & & & & & & 4.56 & 4.81 & 4.88 & 4.71 & 5.14 & 4.69 \\
\hline $\ln \left(\mathrm{POL}_{\mathrm{ED}}\right)$ & & & & & & & & & & & 0.14 & & & & & & & & & & & & \\
\hline & & & & & & & & & & & 1.71 & & & & & & & & & & & & \\
\hline $\ln \left(\mathrm{CORRUP}_{\mathrm{ED}}\right)$ & & & & & & & & & & & & 0.04 & & & & & & & & & & & \\
\hline & & & & & & & & & & & & 1.18 & & & & & & & & & & & \\
\hline $\ln \left(\mathrm{GOVEFF}_{\mathrm{ED}}\right)$ & & & & & & & & & & & & & 0.07 & & & & & & & & & & \\
\hline & & & & & & & & & & & & & 2.01 & & & & & & & & & & \\
\hline $\ln \left(\right.$ POLSTAB $\left._{\mathrm{ED}}\right)$ & & & & & & & & & & & & & & 0.01 & & & & & & & & & \\
\hline & & & & & & & & & & & & & & 0.27 & & & & & & & & & \\
\hline $\ln \left(\mathrm{REGQAL}_{\mathrm{ED}}\right)$ & & & & & & & & & & & & & & & 0.00 & & & & & & 0.03 & 0.09 & \\
\hline & & & & & & & & & & & & & & & -0.01 & & & & & & 0.61 & 2.09 & \\
\hline $\ln \left(\right.$ VOICE $\left._{\mathrm{ED}}\right)$ & & & & & & & & & & & & & & & & 0.13 & & & & & 0.16 & & 0.17 \\
\hline & & & & & & & & & & & & & & & & 3.76 & & & & & 4.32 & & 4.69 \\
\hline $\ln \left(\mathrm{LAW}_{\mathrm{ED}}\right)$ & & & & & & & & & & & & & & & & & 0.06 & & & & & & \\
\hline & & & & & & & & & & & & & & & & & 1.45 & & & & & & \\
\hline ln(TRADEVOL) & 0.50 & 0.51 & 0.50 & 0.53 & 0.51 & 0.49 & 0.47 & 0.47 & 0.39 & 0.40 & 0.55 & 0.53 & 0.53 & 0.50 & 0.50 & 0.53 & 0.54 & 0.40 & 0.31 & 0.33 & 0.35 & 0.35 & 0.34 \\
\hline & 2.93 & 2.98 & 2.90 & 3.11 & 2.93 & 2.90 & 2.75 & 2.77 & 2.29 & 2.36 & 3.04 & 2.92 & 3.05 & 2.93 & 2.84 & 3.11 & 3.00 & 2.38 & 1.89 & 2.07 & 2.24 & 2.23 & 2.21 \\
\hline country $y_{\text {lender }}$ dummies & Yes & Yes & Yes & Yes & Yes & Yes & Yes & Yes & Yes & Yes & Yes & Yes & Yes & Yes & Yes & Yes & Yes & Yes & Yes & Yes & Yes & Yes & Yes \\
\hline country $_{\text {borrower }}$ dummies & Yes & Yes & Yes & Yes & Yes & Yes & Yes & Yes & Yes & Yes & Yes & Yes & Yes & Yes & Yes & Yes & Yes & Yes & Yes & Yes & Yes & Yes & Yes \\
\hline year dummies & Yes & Yes & Yes & Yes & Yes & Yes & Yes & Yes & Yes & Yes & Yes & Yes & Yes & Yes & Yes & Yes & Yes & Yes & Yes & Yes & Yes & Yes & Yes \\
\hline adjusted $\mathrm{R}^{2}$ & 0.834 & 0.834 & 0.834 & 0.835 & 0.834 & 0.835 & 0.835 & 0.835 & 0.837 & 0.838 & 0.834 & 0.834 & 0.835 & 0.834 & 0.834 & 0.836 & 0.834 & 0.838 & 0.841 & 0.842 & 0.846 & 0.843 & 0.846 \\
\hline number of observations & 842 & 842 & 842 & 842 & 842 & 842 & 842 & 842 & 842 & 842 & 842 & 842 & 842 & 842 & 842 & 842 & 842 & 842 & 842 & 842 & 842 & 842 & 842 \\
\hline
\end{tabular}




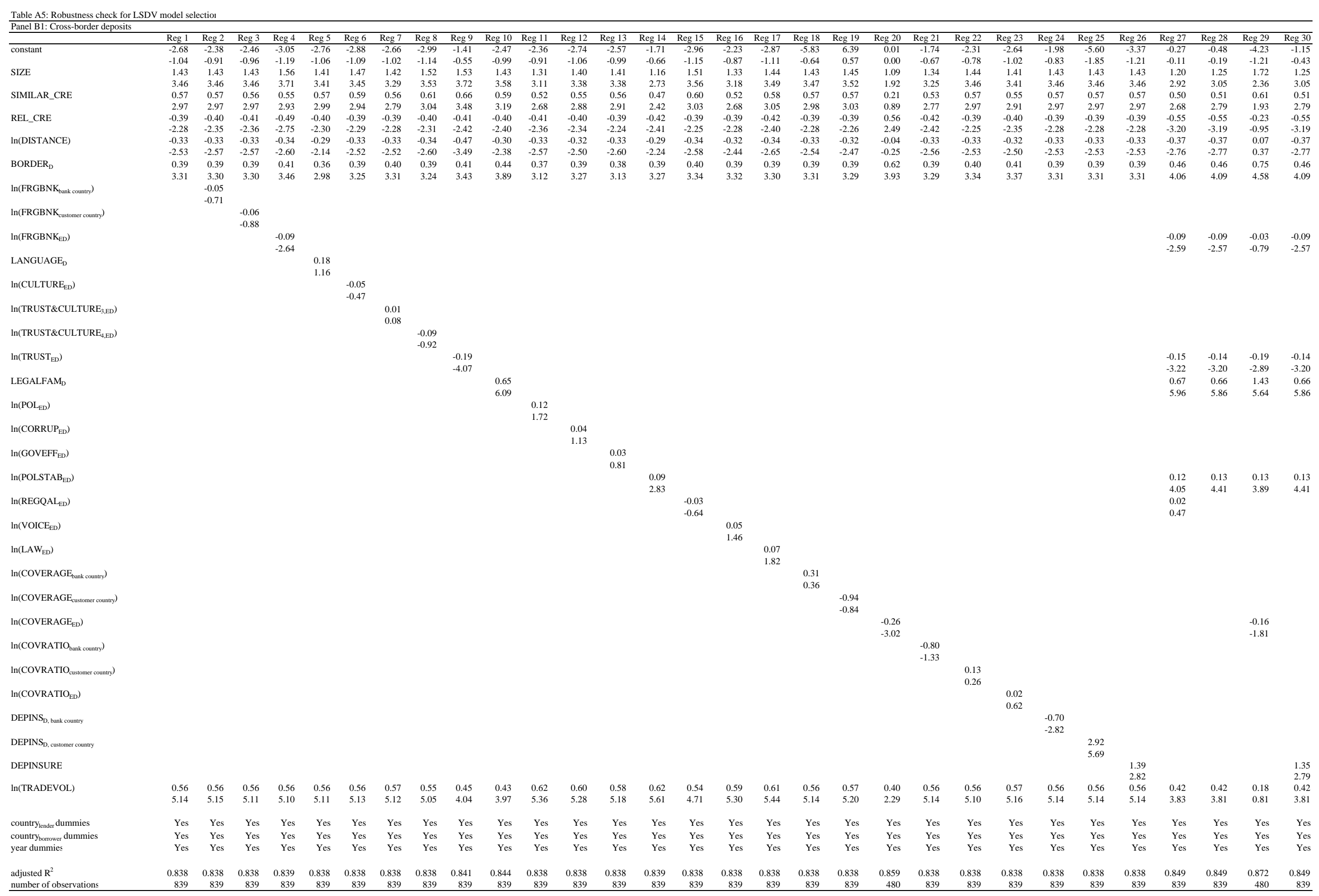




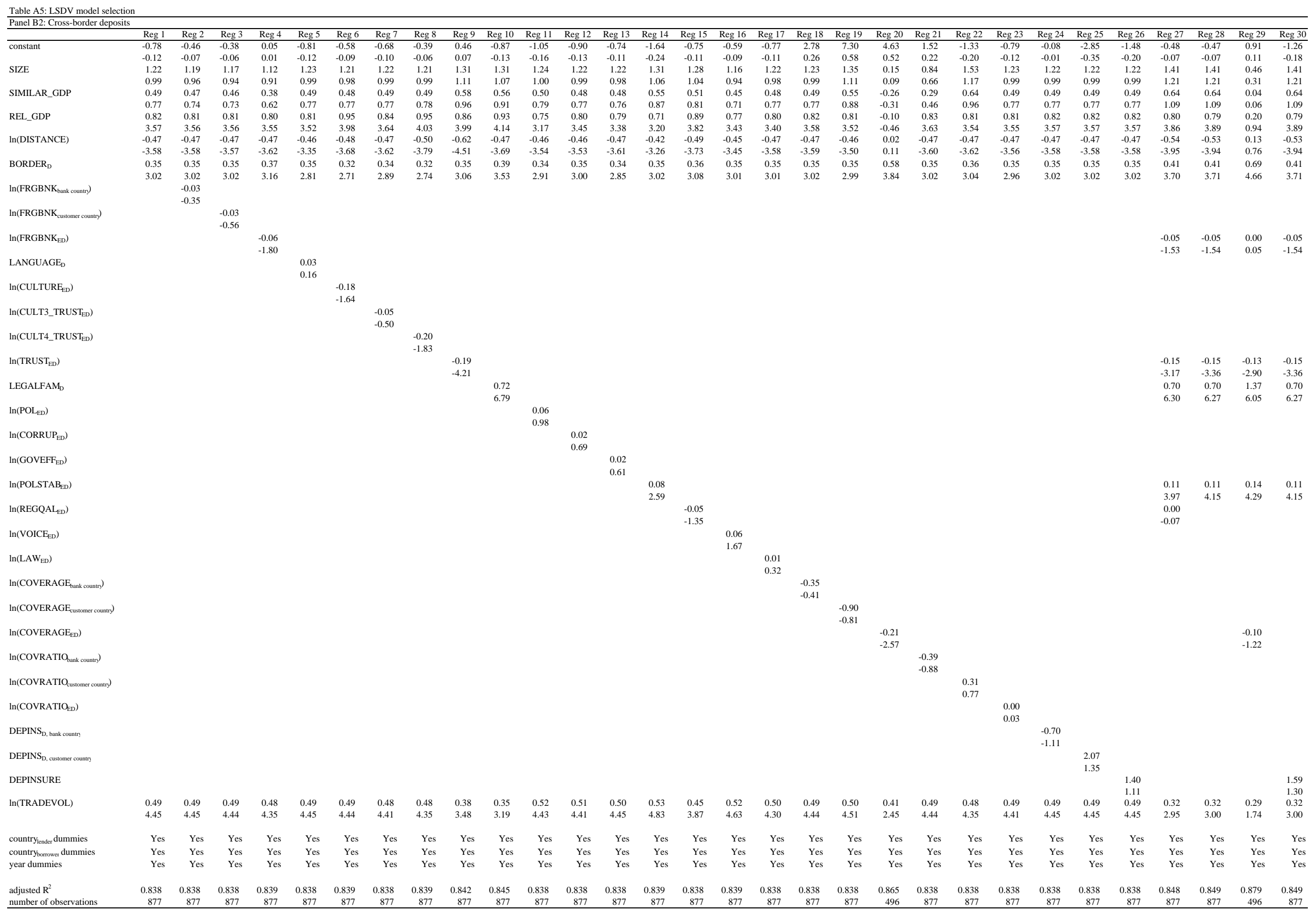


Table A6: Fixed effects model selection

Panel A1: Cross-border loans

\begin{tabular}{|c|c|c|c|c|c|c|c|c|c|c|c|c|c|c|c|}
\hline & Reg 1 & Reg 2 & $\operatorname{Reg} 3$ & Reg 4 & Reg 5 & Reg 6 & Reg 7 & $\operatorname{Reg} 8$ & Reg 9 & $\operatorname{Reg} 10$ & Reg 11 & Reg12 & Reg 13 & Reg 14 & Reg 15 \\
\hline \multirow[t]{2}{*}{ SIZE } & 0.83 & 0.84 & 0.78 & 0.77 & 0.82 & 0.83 & 0.80 & 0.80 & 0.94 & 0.76 & 0.83 & 0.68 & 0.74 & 0.88 & 0.77 \\
\hline & 1.18 & 1.19 & 1.10 & 1.08 & 1.16 & 1.17 & 1.13 & 1.14 & 1.36 & 1.06 & 1.18 & 0.93 & 1.05 & 1.26 & 1.09 \\
\hline \multirow[t]{2}{*}{ SIMILAR_CRE } & -0.20 & -0.20 & -0.20 & -0.20 & -0.21 & -0.20 & -0.18 & -0.18 & -0.16 & -0.20 & -0.26 & -0.20 & -0.18 & -0.17 & -0.26 \\
\hline & -0.92 & -0.94 & -0.93 & -0.92 & -1.01 & -0.94 & -0.83 & -0.85 & -0.78 & -0.94 & -1.20 & -0.92 & -0.85 & -0.78 & -1.20 \\
\hline \multirow[t]{2}{*}{ REL_CRE } & -0.07 & -0.10 & -0.10 & -0.18 & -0.08 & -0.07 & -0.04 & -0.09 & -0.12 & -0.06 & -0.04 & -0.06 & -0.20 & -0.24 & -0.16 \\
\hline & -0.33 & -0.50 & -0.49 & -0.93 & -0.42 & -0.36 & -0.22 & -0.45 & -0.63 & -0.31 & -0.20 & -0.30 & -1.03 & -1.25 & -0.81 \\
\hline \multirow[t]{2}{*}{$\ln \left(\mathrm{FRGBNK}_{\mathrm{ED}}\right)$} & & -0.02 & & -0.02 & & & & & & & & & & & \\
\hline & & -0.59 & & -0.48 & & & & & & & & & & & \\
\hline \multirow[t]{2}{*}{$\ln \left(\right.$ FRGBNK $\left._{\text {bank country }}\right)$} & & & -0.05 & & & & & & & & & & & & \\
\hline & & & -0.79 & & & & & & & & & & & & \\
\hline \multirow[t]{2}{*}{$\ln ($ FRGBNK customer country $)$} & & & & -0.17 & & & & & & & & & -0.16 & -0.17 & -0.17 \\
\hline & & & & -3.59 & & & & & & & & & -3.50 & -3.59 & 3.58 \\
\hline \multirow[t]{2}{*}{$\ln \left(\mathrm{POL}_{\mathrm{ED}}\right)$} & & & & & -0.09 & & & & & & & & & & \\
\hline & & & & & -0.87 & & & & & & & & & & \\
\hline \multirow[t]{2}{*}{$\ln \left(\mathrm{CORRUP} \mathrm{ED}_{\mathrm{ED}}\right)$} & & & & & & -0.02 & & & & & & & & & \\
\hline & & & & & & -0.81 & & & & & & & & & \\
\hline \multirow[t]{2}{*}{$\ln \left(G O V E F F_{E D}\right)$} & & & & & & & 0.02 & & & & & & & & \\
\hline & & & & & & & 0.84 & & & & & & & & \\
\hline \multirow[t]{2}{*}{$\ln \left(\mathrm{POLSTAB}_{\mathrm{ED}}\right)$} & & & & & & & & -0.05 & & & & & -0.04 & & \\
\hline & & & & & & & & -1.89 & & & & & -1.67 & & \\
\hline \multirow[t]{2}{*}{$\ln \left(\mathrm{REGQAL}_{\mathrm{ED}}\right)$} & & & & & & & & & -0.11 & & & & & -0.11 & \\
\hline & & & & & & & & & -2.69 & & & & & -2.73 & \\
\hline \multirow[t]{2}{*}{$\ln \left(\mathrm{VOICE}_{\mathrm{ED}}\right)$} & & & & & & & & & & 0.04 & & & & & \\
\hline & & & & & & & & & & 1.02 & & & & & \\
\hline \multirow[t]{2}{*}{$\ln \left(\mathrm{LAW}_{\mathrm{ED}}\right)$} & & & & & & & & & & & -0.12 & & & & -0.11 \\
\hline & & & & & & & & & & & -1.93 & & & & -1.90 \\
\hline \multirow[t]{2}{*}{$\ln (\mathrm{TRADEVOL})$} & & & & & & & & & & & & 0.14 & & & \\
\hline & & & & & & & & & & & & 0.90 & & & \\
\hline adjusted $\mathrm{R}^{2}$ & 0.938 & 0.938 & 0.938 & 0.939 & 0.938 & 0.938 & 0.938 & 0.938 & 0.938 & 0.938 & 0.938 & 0.938 & 0.939 & 0.939 & 0.939 \\
\hline number of observations & 807 & 807 & 807 & 807 & 807 & 807 & 807 & 807 & 807 & 807 & 807 & 807 & 807 & 807 & 807 \\
\hline
\end{tabular}

Note: In each regression, the dependent variable is the log of bilateral cross-border loan volume. The Fixed Effects model is a two-way fixed analysis with country-pair and time fixed effects and is estimated with White-robust standard errors. For each coefficient, the first row shows the estimated coefficient and the second row the t-statistic. The subscript ED indicates a variable measured as an Euclidean distance where larger values indicate larger differences between bank country and customer country. 
Table A6: Fixed effects model selection

Panel A2: Cross-border loans

\begin{tabular}{|c|c|c|c|c|c|c|c|c|c|c|c|c|c|c|c|c|}
\hline & Reg 1 & Reg 2 & Reg 3 & Reg 4 & Reg 5 & Reg 6 & $\operatorname{Reg} 7$ & Reg 8 & Reg 9 & Reg 10 & Reg 11 & Reg 12 & Reg 13 & Reg 14 & Reg 15 & $\operatorname{Reg} 16$ \\
\hline \multirow[t]{2}{*}{$\overline{\text { SIZE }}$} & -0.13 & -0.18 & -0.26 & -0.32 & -0.15 & -0.16 & -0.15 & -0.18 & -0.06 & -0.23 & -0.10 & -0.49 & -0.34 & -0.25 & -0.35 & -0.63 \\
\hline & -0.18 & -0.25 & -0.35 & -0.46 & -0.22 & -0.22 & -0.21 & -0.26 & -0.08 & -0.32 & -0.15 & -0.67 & -0.49 & -0.35 & -0.49 & -0.85 \\
\hline \multirow[t]{2}{*}{ SIMILAR_GDP } & -0.90 & -0.96 & -0.96 & -1.04 & -0.94 & -0.95 & -0.83 & -0.95 & -0.75 & -0.96 & -0.90 & -0.93 & -1.09 & -0.89 & -0.95 & -0.97 \\
\hline & -1.67 & -1.78 & -1.75 & -1.94 & -1.76 & -1.78 & -1.53 & -1.76 & -1.38 & -1.78 & -1.68 & -1.73 & -2.05 & -1.66 & -1.78 & -1.82 \\
\hline \multirow[t]{2}{*}{ REL_GDP } & 0.98 & 0.94 & 0.92 & 0.86 & 0.98 & 0.98 & 0.98 & 1.06 & 0.79 & 1.07 & 0.92 & 1.01 & 0.87 & 0.67 & 0.76 & 0.78 \\
\hline & 2.46 & 2.38 & 2.32 & 2.14 & 2.46 & 2.48 & 2.46 & 2.59 & 1.99 & 2.68 & 2.23 & 2.54 & 2.15 & 1.68 & 1.89 & 1.94 \\
\hline \multirow[t]{2}{*}{$\ln \left(\mathrm{FRGBNK}_{\mathrm{ED}}\right)$} & & -0.03 & & & & & & & & & & & & & & \\
\hline & & -0.95 & & & & & & & & & & & & & & \\
\hline \multirow[t]{2}{*}{$\ln ($ FRGBNK bank country $)$} & & & -0.08 & & & & & & & & & & & & & \\
\hline & & & -1.30 & & & & & & & & & & & & & \\
\hline \multirow{2}{*}{$\ln ($ FRGBNK customer country $)$} & & & & -0.16 & & & & & & & & & -0.15 & -0.15 & -0.16 & -0.15 \\
\hline & & & & -3.22 & & & & & & & & & -3.16 & -3.19 & -3.23 & -3.1 \\
\hline \multirow[t]{2}{*}{$\ln \left(\mathrm{POL}_{\mathrm{ED}}\right)$} & & & & & -0.06 & & & & & & & & & & & \\
\hline & & & & & -0.55 & & & & & & & & & & & \\
\hline \multirow{2}{*}{$\ln \left(C O R R U P_{E D}\right)$} & & & & & & -0.05 & & & & & & & -0.04 & & & \\
\hline & & & & & & -1.82 & & & & & & & -1.68 & & & \\
\hline \multirow[t]{2}{*}{$\ln \left(G O V E F F_{\mathrm{ED}}\right)$} & & & & & & & 0.04 & & & & & & & & & \\
\hline & & & & & & & 1.29 & & & & & & & & & \\
\hline \multirow[t]{2}{*}{$\ln \left(\mathrm{POLSTAB}_{\mathrm{ED}}\right)$} & & & & & & & & -0.04 & & & & & & & & \\
\hline & & & & & & & & -1.29 & & & & & & & & \\
\hline \multirow[t]{2}{*}{$\ln \left(\mathrm{REGQAL}_{\mathrm{ED}}\right)$} & & & & & & & & & -0.13 & & & & & -0.12 & -0.13 & -0.12 \\
\hline & & & & & & & & & -2.86 & & & & & -2.87 & -2.9 & -2.88 \\
\hline \multirow[t]{2}{*}{$\ln \left(\mathrm{VOICE}_{\mathrm{ED}}\right)$} & & & & & & & & & & 0.06 & & & & & 0.07 & 0.06 \\
\hline & & & & & & & & & & 1.80 & & & & & 1.84 & 1.7 \\
\hline \multirow[t]{2}{*}{$\ln \left(\mathrm{LAW}_{\mathrm{ED}}\right)$} & & & & & & & & & & & -0.05 & & & & & \\
\hline & & & & & & & & & & & -0.74 & & & & & \\
\hline \multirow[t]{2}{*}{$\ln (\mathrm{TRADEVOL})$} & & & & & & & & & & & & 0.27 & & & & 0.21 \\
\hline & & & & & & & & & & & & 2.21 & & & & 1.78 \\
\hline adjusted $\mathrm{R}^{2}$ & 0.930 & 0.930 & 0.930 & 0.931 & 0.930 & 0.930 & 0.930 & 0.930 & 0.931 & 0.931 & 0.930 & 0.931 & 0.931 & 0.932 & 0.932 & 0.932 \\
\hline number of observations & 842 & 842 & 842 & 842 & 842 & 842 & 842 & 842 & 842 & 842 & 842 & 842 & 842 & 842 & 842 & 842 \\
\hline
\end{tabular}


Table A6: Fixed effects model selection Panel B1: Cross-border deposits

\begin{tabular}{|c|c|c|c|c|c|c|c|c|c|c|c|c|c|c|c|c|c|c|c|c|}
\hline 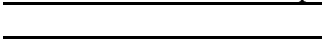 & Reg 1 & Reg 2 & Reg 3 & Reg 4 & Reg 5 & Reg 6 & Reg 7 & Reg 8 & Reg 9 & Reg 10 & Reg 11 & Reg 12 & Reg 13 & Reg 14 & Reg 15 & Reg 16 & Reg 17 & Reg 18 & Reg 19 & Reg 20 \\
\hline \multirow[t]{2}{*}{ SIZE } & 2.50 & 2.51 & 2.46 & 2.48 & 2.52 & 2.52 & 2.46 & 2.53 & 2.52 & 2.65 & 2.50 & 1.94 & 2.63 & 2.56 & 2.60 & 2.55 & 2.70 & 2.69 & 2.75 & 2.53 \\
\hline & 3.32 & 3.31 & 3.29 & 3.29 & 3.34 & 3.35 & 3.28 & 3.37 & 3.36 & 3.50 & 3.30 & 2.67 & 3.31 & 3.37 & 3.38 & 3.40 & 3.56 & 3.57 & 3.62 & 3.37 \\
\hline \multirow[t]{2}{*}{ SIMILAR_CRE } & 0.83 & 0.83 & 0.83 & 0.83 & 0.85 & 0.85 & 0.86 & 0.81 & 0.84 & 0.84 & 0.79 & 0.72 & 0.85 & 0.79 & 0.84 & 0.83 & 0.83 & 0.79 & 0.75 & 0.81 \\
\hline & 4.13 & 4.13 & 4.14 & 4.14 & 4.15 & 4.20 & 4.18 & 4.05 & 4.16 & 4.25 & 3.84 & 3.57 & 4.20 & 3.88 & 4.16 & 4.11 & 4.25 & 3.96 & 3.74 & 4.04 \\
\hline \multirow[t]{2}{*}{ REL_CRE } & -0.17 & -0.18 & -0.22 & -0.21 & -0.16 & -0.16 & -0.14 & -0.14 & -0.18 & -0.18 & -0.15 & -0.22 & -0.14 & -0.20 & -0.17 & -0.12 & -0.13 & -0.11 & -0.14 & -0.16 \\
\hline & -0.84 & -0.86 & -1.06 & -1.01 & -0.77 & -0.76 & -0.68 & -0.70 & -0.87 & -0.89 & -0.75 & -1.11 & -0.69 & -0.98 & -0.84 & -0.61 & -0.65 & -0.56 & -0.69 & -0.76 \\
\hline \multirow[t]{2}{*}{$\ln \left(F_{R G B N K}{ }_{\mathrm{ED}}\right)$} & & $-0,00$ & & & & & & & & & & & & & & & & & & -0.01 \\
\hline & & -0.12 & & & & & & & & & & & & & & & & & & -0.29 \\
\hline \multirow[t]{2}{*}{$\ln \left(\right.$ FRGBNK $\left._{\text {bank country }}\right)$} & & & -0.05 & & & & & & & & & & & & & & & & & \\
\hline & & & -1.48 & & & & & & & & & & & & & & & & & \\
\hline \multirow[t]{2}{*}{$\ln \left(\right.$ FRGBNK $\left._{\text {customer country }}\right)$} & & & & -0.05 & & & & & & & & & & & & & & & & \\
\hline & & & & -0.98 & & & & & & & & & & & & & & & & \\
\hline \multirow[t]{2}{*}{$\ln \left(\mathrm{POL}_{\mathrm{ED}}\right)$} & & & & & 0.08 & & & & & & & & & & & & & & & \\
\hline & & & & & 0.71 & & & & & & & & & & & & & & & \\
\hline \multirow[t]{2}{*}{$\ln \left(C O R R U P_{\mathrm{ED}}\right)$} & & & & & & 0.04 & & & & & & & & & & 0.05 & 0.05 & 0.05 & 0.05 & \\
\hline & & & & & & 2.21 & & & & & & & & & & 2.28 & 2.59 & 2.37 & 2.44 & \\
\hline \multirow[t]{2}{*}{$\ln \left(G O V E F F_{E D}\right)$} & & & & & & & 0.04 & & & & & & & & & & & & & \\
\hline & & & & & & & 1.42 & & & & & & & & & & & & & \\
\hline \multirow[t]{2}{*}{$\ln \left(\mathrm{POLSTAB}_{\mathrm{ED}}\right)$} & & & & & & & & 0.06 & & & & & & & & 0.06 & 0.06 & 0.06 & 0.06 & 0.06 \\
\hline & & & & & & & & 1.94 & & & & & & & & 1.97 & 1.97 & 2.10 & 2.19 & 1.96 \\
\hline \multirow[t]{2}{*}{$\ln \left(\mathrm{REGQAL}_{\mathrm{ED}}\right)$} & & & & & & & & & -0.01 & & & & & & & & & & & \\
\hline & & & & & & & & & -0.29 & & & & & & & & & & & \\
\hline \multirow[t]{2}{*}{$\ln \left(\mathrm{VOICE}_{\mathrm{ED}}\right)$} & & & & & & & & & & -0.09 & & & & & & & -0.09 & -0.09 & -0.09 & \\
\hline & & & & & & & & & & -3.20 & & & & & & & -3.27 & -3.12 & -3.10 & \\
\hline \multirow[t]{2}{*}{$\ln \left(\mathrm{LAW}_{\mathrm{ED}}\right)$} & & & & & & & & & & & -0.09 & & & & & & & -0.08 & -0.08 & \\
\hline & & & & & & & & & & & -1.93 & & & & & & & -1.91 & -1.79 & \\
\hline \multirow[t]{2}{*}{$\ln ($ COVRATIO bank country $)$} & & & & & & & & & & & & -0.85 & & & & & & & & \\
\hline & & & & & & & & & & & & -2.32 & & & & & & & & \\
\hline \multirow[t]{2}{*}{$\ln ($ COVRATIO customer countrr $)$} & & & & & & & & & & & & & 0.20 & & & & & & & \\
\hline & & & & & & & & & & & & & 0.74 & & & & & & & \\
\hline \multirow[t]{2}{*}{$\ln \left(\right.$ COVRATIO $\left._{\mathrm{ED}}\right)$} & & & & & & & & & & & & & & 0.06 & & & & & 0.06 & \\
\hline & & & & & & & & & & & & & & 1.84 & & & & & 1.91 & \\
\hline \multirow[t]{2}{*}{$\ln (\mathrm{TRADEVOL})$} & & & & & & & & & & & & & & & -0.12 & & & & & \\
\hline & & & & & & & & & & & & & & & 0.65 & & & & & \\
\hline adjusted $\mathrm{R}^{2}$ & 0.944 & 0.944 & 0.944 & 0.944 & 0.944 & 0.944 & 0.944 & 0.944 & 0.944 & 0.945 & 0.944 & 0.945 & 0.944 & 0.944 & 0.944 & 0.944 & 0.945 & 0.945 & 0.945 & 0.944 \\
\hline number of observations & 839 & 839 & 839 & 839 & 839 & 839 & 839 & 839 & 839 & 839 & 839 & 839 & 839 & 839 & 839 & 839 & 839 & 839 & 839 & 839 \\
\hline
\end{tabular}


Table A6: Fixed effects model selection

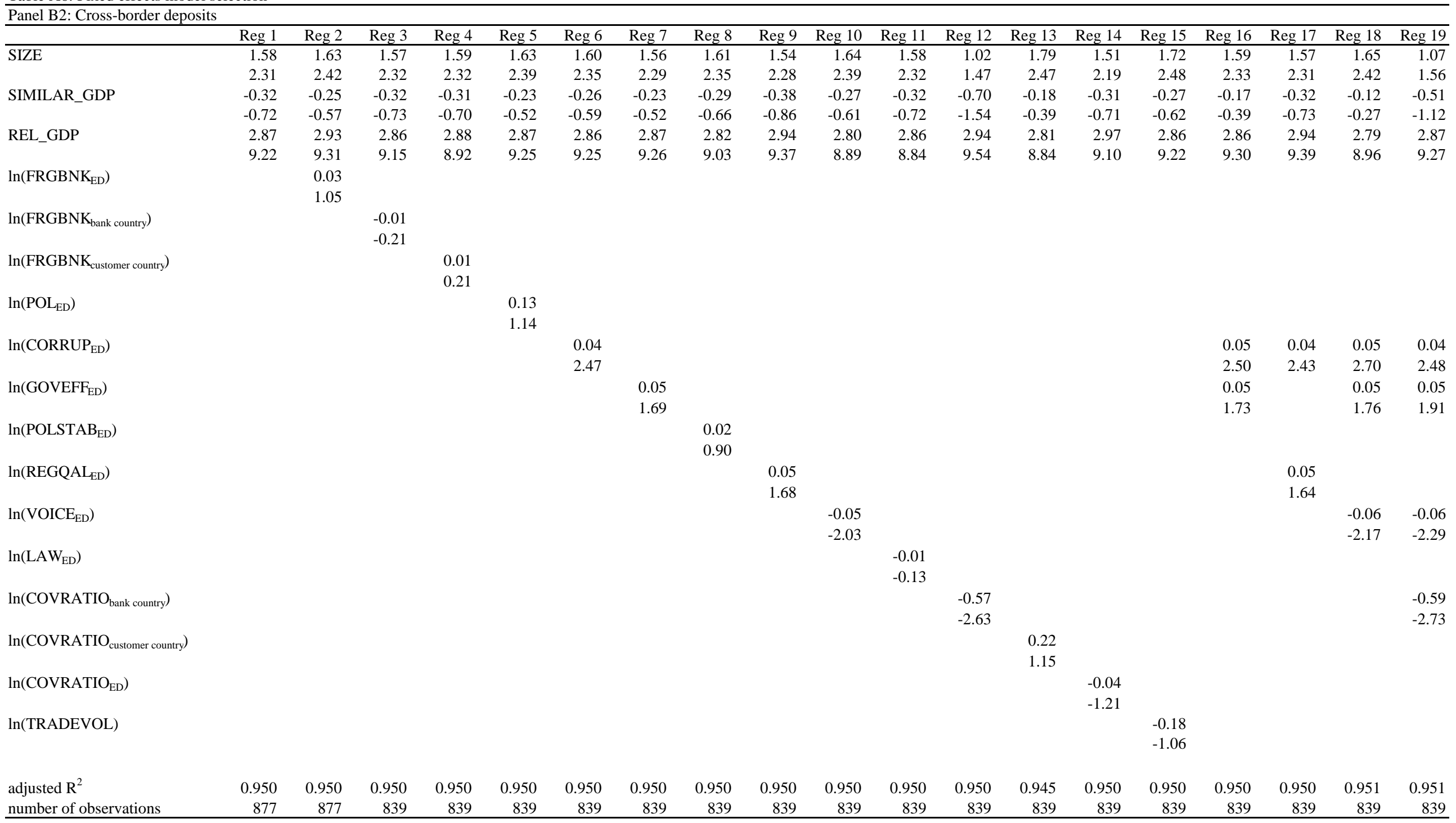

